\title{
Juris Hofmanis
}

\section{IEKAISĪGIE UN NEIEKAISĪGIE RISKA FAKTORI IEGŪTAS AORTAS VĀRSTUḶA STENOZES GADĪJUMĀ}

Promocijas darba kopsavilkums medicinas doktora zinātniskā grāda iegūšanai 


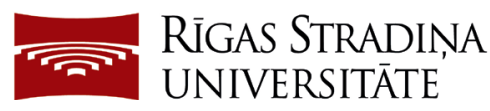

\author{
Juris Hofmanis
}

\title{
PIEKAISĪGIE UN NEIEKAISĪGIE RISKA FAKTORI IEGŪTAS AORTAS VĀRSTUL̨A STENOZES GADĪJUMĀ
}

\author{
Promocijas darba kopsavilkums \\ medicīnas doktora zinātniskā grāda iegūšanai
}

Specialitāte - internā medicīna

Rīga, 2019 
Promocijas darbs izstrādāts Rīgas Stradiṇa universitātē.

Darba zinātniskie vadītāji:

Dr. med. asociētais profesors Vitolds Mackēvičs,

Rīgas Stradiṇa universitāte, Latvija

Dr. biol. profesors Pēteris Tretjakovs

Rīgas Stradiṇa universitāte, Latvija

Oficiālie recenzenti:

Dr. med. profesors Oskars Kalējs,

Rīgas Stradiṇa universitāte, Latvija

Dr. med. Ainārs Rudzītis,

P. Stradinna Klīniskā universitātes slimnīca,

Latvijas Kardiologijas centrs, Latvija

$M D, P h D$, acosiētais profesors Domenico Di Raimondo,

Palermo Universitāte, Itālija

Promocijas darba aizstāvēšana notiks 2019. gada 12. septembrī plkst. 12.00 Rīgas Stradinna universitātes Medicīnas promocijas padomes atklātā sēdē Rīgā, Dzirciema ielā 16, Hipokrāta auditorijā.

Ar promocijas darbu var iepazīties RSU bibliotēkā un RSU tīmekḷa vietnē: www.rsu.lv.

Promocijas padomes sekretāre:

Dr. med. asociētā profesore Ilze Konrāde 


\section{SATURS}

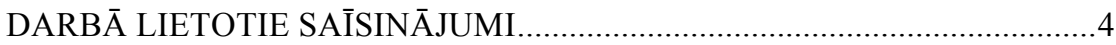

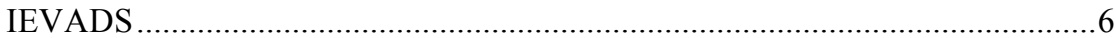

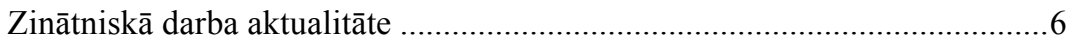

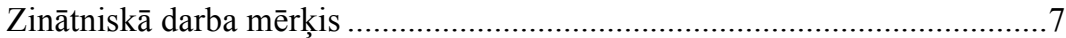

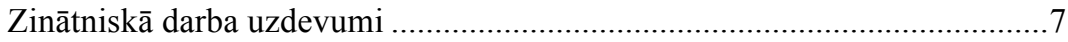

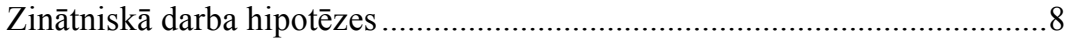

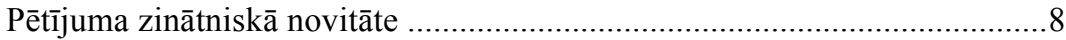

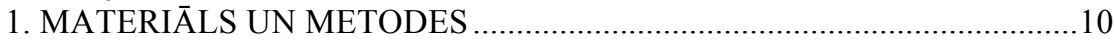

1.1. Pētījuma populācija ........................................................................... 10

1.2. Pētījuma personu iekḷaušanas un izslēgšanas kritēriji............................11

1.3. Aortas vārstuḷa stenozes diagnostika un izvērtēšana..............................13

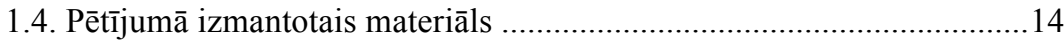

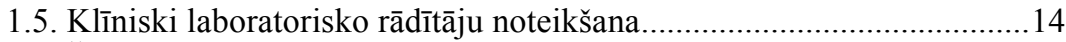

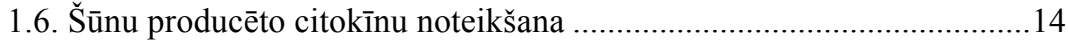

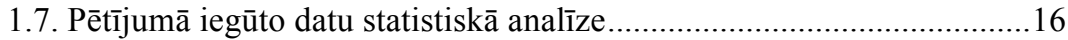

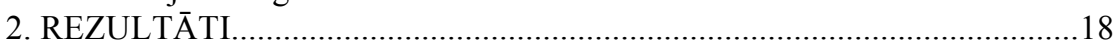

2.1. Pētìjuma pacientu un kontroles indivīdu raksturojums .........................18

2.2. Šūnu producēto citokīnu analīžu rezultāti ...........................................20

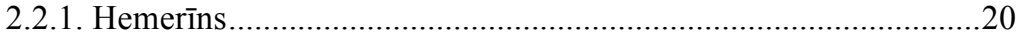

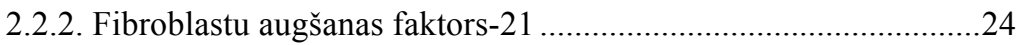

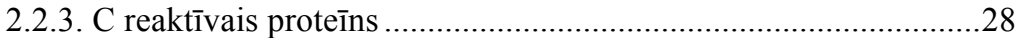

2.2.4. Matrices metaloproteināzes un to audu inhibitori ........................29

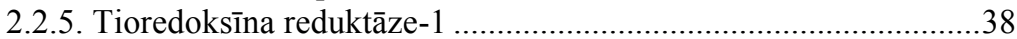

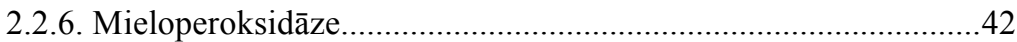

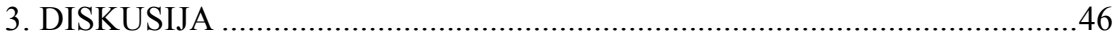

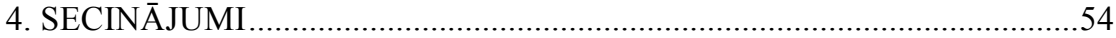

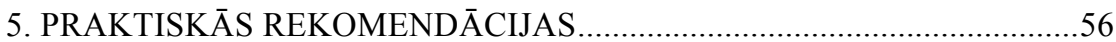

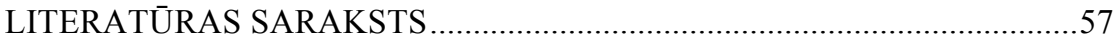

PUBLICĒTIE RAKSTI, ZIN̦OJUMI PAR DARBA TËMU .............................59

Publikācijas recenzētos medicīniskajos izdevumos ......................................59

Mutiskie ziṇojumi kongresos un konferencēs ..............................................59

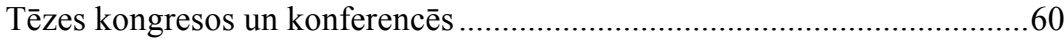




\section{DARBĀ LIETOTIE SAĪSINĀJUMI}

\begin{tabular}{|c|c|c|c|}
\hline 5'-NT & 5'-nukleotidāze & $\begin{array}{c}\text { MMP- } \\
1,2,3,7,9,11\end{array}$ & $\begin{array}{l}\text { matrices metaloproteināzes- } \\
1,2,3,7,9,11\end{array}$ \\
\hline $\mathrm{ABI}$ & potītes brahiālais indekss & MPO & mieloperoksidāze \\
\hline ABL-H & $\begin{array}{l}\text { augsta blīvuma } \\
\text { lipoproteīnu holesterīns }\end{array}$ & MV & mitrālais vārstulis \\
\hline AKE & $\begin{array}{l}\text { angiotenzīna } \\
\text { konvertējošais enzīms }\end{array}$ & $\begin{array}{l}\text { NADPH } \\
\text { oksidāze }\end{array}$ & $\begin{array}{l}\text { nikotīnamīda adenīna } \\
\text { dinukleotīda fosfāta } \\
\text { oksidāze }\end{array}$ \\
\hline ALP & sārmainā fosfatāze & $\mathrm{NF}-\mathrm{k} \beta$ & kodola faktors kappa $\beta$ \\
\hline Ang I & angiotenzīns I & NO & slāpekḷa oksīds \\
\hline Ang II & angiotenzīns II & NOS & slāpekḷa oksīda sintāze \\
\hline apoA-1 & apolipoproteīns A-1 & NPP1 & $\begin{array}{l}\text { ektonukleotīdu } \\
\text { pirofosfatāze/ } \\
\text { fosfodiesterāze } 1\end{array}$ \\
\hline ASK1 & $\begin{array}{l}\text { apoptozes signālus } \\
\text { regulējošā kināze-1 }\end{array}$ & NPV & $\begin{array}{l}\text { negatīvā prognostiskā } \\
\text { vērtība }\end{array}$ \\
\hline AUC & laukums zem ROC līknes & $\mathrm{O}_{2}^{-}$ & superoksīds \\
\hline AV & aortas vārstulis & $\mathrm{ONOO}^{-}$ & peroksinitrīts \\
\hline AVA & aortas vārstuḷa atvere & ox-ABL-H & $\begin{array}{l}\text { oksidētais augsta blīvuma } \\
\text { lipoproteīnu holesterīns }\end{array}$ \\
\hline AVS & aortas vārstuḷa stenoze & ox-ZBL & $\begin{array}{l}\text { oksidētais zema blīvuma } \\
\text { lipoproteīns }\end{array}$ \\
\hline bFGF & $\begin{array}{l}\text { pamata fibroblastu } \\
\text { augšanas faktors }\end{array}$ & PAS & perifēro artēriju slimības \\
\hline $\mathrm{BH} 4$ & tetrahidrobiopterīns & PG & spiediena gradients \\
\hline BPM-2 & $\begin{array}{l}\text { kaulu morfogēnais } \\
\text { proteīns }\end{array}$ & PPV & $\begin{array}{l}\text { pozitīvā prognostiskā } \\
\text { vērtība }\end{array}$ \\
\hline ChemR23 & hemerīna receptors 23 & Pro-MMP & proenzīmi \\
\hline $\mathrm{Cl}^{-}$ & hlora anjons & PW & pulsa vilņa doplerogrāfija \\
\hline CRP & C-reaktīvais proteīns & RAA & $\begin{array}{l}\text { renīna-angiotenzīna- } \\
\text { aldosterona }\end{array}$ \\
\hline DNS & dezoksiribonukleīnskābe & ROC līkne & $\begin{array}{l}\text { No anglu val. Receiver- } \\
\text { Operating Characteristic } \\
\text { Curve }\end{array}$ \\
\hline $\mathrm{EF}$ & izsviedes frakcija & ROS & reaktīvās skābekḷa daḷiņas \\
\hline EGĀ & $\begin{array}{l}\text { eritrocītu grimšanas } \\
\text { âtrums }\end{array}$ & $\mathrm{Se}$ & jutīgums \\
\hline
\end{tabular}




\begin{tabular}{|c|c|c|c|}
\hline Ehokg & ehokardiogrāfija & SOD & superoksīda dismutāze \\
\hline FGF-21 & $\begin{array}{l}\text { fibroblastu augšanas } \\
\text { faktors- } 21\end{array}$ & $\mathrm{Sp}$ & specifiskums \\
\hline GPR1 & $\begin{array}{l}\text { G-proteīniem piesaistītais } \\
\text { receptors } 1\end{array}$ & SV & izsviedes tilpums \\
\hline $\mathrm{H}_{2} \mathrm{O}_{2}$ & ūdeņraža peroksīds & SVI & $\begin{array}{l}\text { indeksētais izsviedes } \\
\text { tilpums }\end{array}$ \\
\hline $\mathrm{HOCI}$ & hipohlorskābe & TG & triglicerīdi \\
\hline hs-CRP & $\begin{array}{l}\text { augsti jutīgais C-reaktīvais } \\
\text { proteīns }\end{array}$ & TGF & $\begin{array}{l}\text { transformējošais augšanas } \\
\text { faktors }\end{array}$ \\
\hline IGF1 & $\begin{array}{l}\text { insulīnam līdzīgais } \\
\text { augšanas faktors } 1\end{array}$ & TGF-1 $\beta$ & $\begin{array}{l}\text { transformējošais augšanas } \\
\text { faktors- } 1 \beta\end{array}$ \\
\hline IL-1 $\beta$ & interleikīns-1 $\beta$ & TGF- $\beta$ & $\begin{array}{l}\text { transformējošais augšanas } \\
\text { faktors- } \beta\end{array}$ \\
\hline IL-2 & interleikīns-2 & TIMP & $\begin{array}{l}\text { matrices metalproteināzes } \\
\text { audu inhibitors }\end{array}$ \\
\hline IL-6 & interleikīns-6 & TIMP-1,3 & $\begin{array}{l}\text { matrices metaloproteināžu } \\
\text { audu inhibitors- } 1,3\end{array}$ \\
\hline IMT & $\begin{array}{l}\text { intīmas un mēdijas slāņa } \\
\text { biezums }\end{array}$ & TNF- $\alpha$ & tumora nekrozes faktors- $\alpha$ \\
\hline $\mathrm{KH}$ & kopējais holesterīns & Trx & tioredoksīns \\
\hline KK & kreisais kambaris & TrxR & tioredoksīna reduktāze \\
\hline KK EDV & $\begin{array}{l}\text { kreisā kambara beigu } \\
\text { diastoles tilpums }\end{array}$ & TrxR1,2,3 & $\begin{array}{l}\text { tioredoksīna reduktāze- } \\
1,2,3\end{array}$ \\
\hline KK ESV & $\begin{array}{l}\text { kreisā kambara beigu } \\
\text { sistoles tilpums }\end{array}$ & VEGF & $\begin{array}{l}\text { asinsvadu endotēlija } \\
\text { augšanas faktors }\end{array}$ \\
\hline ĶMI & ķermeņa masas indekss & VIC & vārstuḷa intersticiālās šūnas \\
\hline Lp(a) & lipoproteīns a & VTI & ātruma laika integrālis \\
\hline LVOT & $\begin{array}{l}\text { kreisā kambara izplūdes } \\
\text { trakts }\end{array}$ & ZBL-H & $\begin{array}{l}\text { zema blīvuma lipoproteīnu } \\
\text { holesterīns }\end{array}$ \\
\hline MMP & matrices metaloproteināze & & \\
\hline
\end{tabular}




\section{IEVADS}

\section{Zinātniskā darba aktualitāte}

Lasot pašreiz pieejamos literatūras datus par aortas vārstuḷa stenozes (AVS) veidošanos un attīstību, varētu domāt, ka viss ir izzināts un skaidrs. Taču par spīti tam, ka pēdējo apmēram 10 gadu laikā veikti daudzi bioķīmiski, molekulāri un gēnu pētījumi, nav pilnībā skaidras atbildes par slimības viennozīmīgu etiologiiju un patoǵenēzi. Visās publikācijās ir vārdi: “jādomā, iespējams"; daudzi pētījumi veikti, balstoties uz operācijas laikā iegūto histologisko materiālu. Ētisku apsvērumu dēl ir grūti veidot kontroles grupas. Tas mudina izzināt situāciju Latvijas populācijā un veikt pētniecisku darbu, lai meklētu atšķirīgo un kopīgo AVS dažādās smaguma pakāpēs; meklētu asins plazmā un serumā biomarķierus, ar kuru palīdzību varētu prognozēt slimības attīstību.

Kalcificējoša AVS izpaužas ar aortas vārstuļa (AV) viru fibrokalcifisko remodelāciju (pārveidošanos), kas ir lēni noritošs hroniska iekaisuma un kalcifikācijas process ar pilnībā neizzinātu un neviennozīmīgu etiologiju un patoǵenēzi (Lindman et al., 2016; Pawade et al., 2015; Zeng et al., 2017; Kanwar et al., 2018). Nav medikamentozas ārstēšanas, lai apturētu vai aizkavētu slimības progresēšanu. Vienīgā pieejamā ārstēšana ir ķirurğiska AV nomaiṇa vai transkatetrāla aortas vārstuḷa implantācija. (Pawade et al., 2015). Pieaugot cilvēku dzīvildzei, pieaug to pacientu skaits, kuriem ir klīniski nozīmīga AVS (Bonow et al., 2015). Gandrīz 25\% cilvēku pēc 65 gadu vecuma ehokardiogrāfiski (Ehokg) atrod AV sklerozi, un apmēram 17\% no šiem cilvēkiem turpmāk attīstās AVS. Vidējais laiks no AV sklerozes diagnostikas līdz vidējas un smagas AVS attīstībai ir 6-8 gadi. AVS izplatība pieaug līdz ar 
vecumu: $50-59$ gadu vecumā to sastop $0,2 \%, 60-69$ gadu vecumā $-1,3 \%$, bet 80-89 gadu vecumā - līdz 9,8\% pacientu (Eveborn et al., 2013).

AVS ir visizplatītākā vārstuļu slimība ASV un Eiropā un ir otrais biežākais iemesls sirds operācijai (Eveborn et al., 2013).

\section{Zinātniskā darba mērḳis}

Analizēt un noskaidrot, kuras no iekaisuma un kalcifikācijas procesā iesaistītajām šūnu producētajām regulējošām molekulām (citokīniem) būtiskāk ietekmē aortas vārstuḷa stenozes rašanās un attīstības procesu katrā no trim stenozes smaguma pakāpēm.

Identificēt iespējamos biomarķierus, kurus potenciāli varētu izmantot vieglas pakāpes AVS diagnostikai.

\section{Zinātniskā darba uzdevumi}

1. AVS pacientu (visu triju smaguma pakāpju) un kontroles grupas indivīdu atlase atbilstoši pētījuma nosacījumiem pēc veiktās Ehokg parametriem.

2. Laboratorisko izmeklējumu veikšana visiem pētījumā iesaistītajiem, nosakot: holesterīnu ar frakcijām, fibrinogēnu, C-reaktīvo proteīnu (CRP), augsti jutīgo C-reaktīvo proteīnu (hs-CRP), hemerīnu, fibroblastu augšanas faktoru-21 (FGF-21), matrices metaloproteināzes1,3,9 (MMP-1,3,9), matrices metaloproteināžu audu inhibitorus-1,3 (TIMP-1,3), transformējošo augšanas faktoru (TGF), tioredoksīna reduktāzi-1 (TrxR1), mieloperoksidāzi (MPO).

3. Izvērtēt analī̌̌u rezultātus, salīdzinot kontroles grupu un AVS grupu un visās trijās AVS smaguma pakāpēs. 
4. Atrast pietiekami informatīvu un labu biomarķieri vieglas aortas vārstuḷa stenozes diagnosticēšanai.

5. Izvērtêt noteikto lipīdu frakciju saistību ar AVS dažādās tās smaguma pakāpēs.

6. Izvērtēt oksidatīvā stresa jauno biomarķieru līmeni dažādās AVS smaguma pakāpēs.

\section{Zinātniskā darba hipotēzes}

1. Iekaisīgiem un neiekaisīgiem faktoriem - šūnu producētām regulējošām molekulām (citokīniem) - ir būtiska nozīme kalcificējošas AVS attīstībā un tie nosaka tās prognozi.

2. Lipīdu frakciju līmeņa izmaiņas AVS pacientiem nav viennozīmīgi vērtējamas kā absolūtais riska kritērijs.

3. Oksidatīvais stress ir saistīts ar AVS visās tās smaguma pakāpēs.

\section{Pētījuma zinātniskā novitāte}

Pētījumā pirmoreiz Latvijas populācijā ir analizēti dažāda vecuma kalcificējošas AVS pacientu asins plazmas un seruma bioķīmiskie rādītāji visās trijās AVS smaguma pakāpes grupās un iegūtie rezultāti ir izvērtēti salīdzinājumā ar kontroles indivīdiem.

Zinot jaunākos pētījumus par kalcificējošas AVS etiopatoǵenēzi, šajā darbā tika izvēlēts noteikt tos iespējamos biomarķierus (hemerīns, FGF-21, tioredoksīna reduktāze-1, mieloperoksidāze), kas līdz šim AVS pacientiem nav pētîti.

Visi iegūtie pētījumā noteikto biomarḳieru rezultāti tiek salīdzināti dažādās AVS smaguma pakāpēs, līdz ar to var detalizētāk spriest par katrā stenozes pakāpē dominējošiem patoǵenētiskajiem procesiem. 
Tika meklētas sakarības starp biomarķieriem, kā arī starp lip̄idu frakcijām un biomarķieriem, un, analizējot lipīdu frakcijas, ir noteikts, ka dislipidēmija nav viennozīmīga AVS pacientiem. Tiek pamatota oksidatīvā stresa loma AVS attīstībā. 


\section{MATERIĀLS UN METODES}

\subsection{Pētījuma populācija}

Klīniski analītiskais pētījums "Iekaisīgie un neiekaisīgie riska faktori iegūtas aortas vārstuḷa stenozes gadījumā” ir jaukta tipa prospektīvs gadījumakontroles pētījums.

Pētījums veikts ar Rīgas Stradiņa universitātes Ėtikas komitejas ațauju. Ētikas komitejas sēdes datums 12.09.2013. Pētījuma protokols atbilst 1975. gada Helsinku deklarācijas ètikas vadlīnijām. No 2013. gada 1. janvāra līdz 2016. gada 31. decembrim tika veikta pacientu atlase dažādās Latvijas slimnīcās un ambulatorajās iestādēs - Vidzemes slimnīcā (Valmiera), P. Stradiña Klīniskās universitātes slimnīcā (Rīga) un Zemgales veselības centrā (Jelgava). 102 cilvēki tika brīvprātīgi atlasīti pēc iekḷaušanas un izslēgšanas kritērijiem un iedalīti divās pamatgrupās: kontroles grupā un AV stenozes grupā; skatīt 1.1. tabulu. Kontroles grupā tika iekļauti cilvēki bez AV stenozes vecumā no 50 līdz 80 gadiem, kas atbilst AV stenozes pacientu vecumam pēc 2012. gada Eiropas Kardiologu biedrības un Eiropas Sirds un torakālo ķirurgu asociācijas darba grupas sirds vārstuḷu slimību ārstēšanas vadlīnijām. (Vahanian et al., 2012). Kontroles grupa tika izveidota ar mērķi noteikt citokīnu referentās vērtības un tās salīdzināt ar aortas stenozes pacientu rezultātiem. Pētījuma tika iekļauti 28 (27\%) vīrieši un 74 (73\%) sievietes. No katra pētījumā iekḷautā cilvēka tika iegūta rakstiski apstiprināta informēta cilvēka piekrišana dalībai pētījumā. 


\section{Pētījuma personu pamatdati}

\begin{tabular}{|c|c|c|c|c|c|}
\hline & & $\begin{array}{c}\text { Kontrole, } \\
\mathrm{n}=50\end{array}$ & $\begin{array}{c}\text { AV viegla } \\
\text { stenoze } \\
\mathrm{n}=18\end{array}$ & $\begin{array}{c}\text { AV vidēja } \\
\text { stenoze, } \\
\mathrm{n}=19\end{array}$ & $\begin{array}{c}\text { AV smaga } \\
\text { stenoze, } \\
\mathrm{n}=15\end{array}$ \\
\hline $\begin{array}{l}\text { Dzimums, } \\
(\%)\end{array}$ & $\begin{array}{c}\text { Vīrieši } \\
\text { Sievietes }\end{array}$ & $\begin{array}{l}11(22,0) \\
39(78,0)\end{array}$ & $\begin{array}{c}2(11,1) \\
16(88,9)\end{array}$ & $\begin{array}{c}8(42,1) \\
11(57,9)\end{array}$ & $\begin{array}{l}7(46,7) \\
8(53,3)\end{array}$ \\
\hline Vecums, gadi & $\begin{array}{c}M d n \\
(I Q R)\end{array}$ & $\begin{array}{c}62 \\
(57-75)\end{array}$ & $\begin{array}{c}71 \\
(65-75)\end{array}$ & $\begin{array}{c}74 \\
(65-79)\end{array}$ & $\begin{array}{c}65 \\
(60-74)\end{array}$ \\
\hline
\end{tabular}

\subsection{Pētījuma personu iekḷaušanas un izslēgšanas kritēriji}

Pētījuma sākumā no katras personas abās pētījuma grupās tika ievākta slimību anamnēze, veikta personu anketēšana par kardiovaskulārās sistēmas stāvokli un jautājumiem, kas saistīti ar iekḷaušanas un izslēgšanas kritērijiem, lietotajiem medikamentiem un veiktajiem izmeklējumiem. Pirms iekḷaušanas pētījumā tika iegūti un analizēti:

- pacienta vispārējie/demogrāfiskie dati;

- subjektīvā stāvokḷa dati (kardiovaskulāro slimību anamnēze, mērkstiecīgi jautājumi kardiovaskulāro slimību izzināšanai);

- laboratoriskie dati (pilna asins aina + eritrocītu grimšanas ātrums (EGĀ), asins bioḳīmiskie rādītāji);

- noteikts "potītes brahiālais" indekss (ABI);

- abpusēji mērīts intīmas un mēdijas slāņa biezums (IMT, intimamedia thickness) kopējā miega artērijā (arteria carotis comunis);

- ehokardiogrāfija, kas apstiprina vai izslēdz aortas vārstuļa stenozi.

Indivīdi kontroles grupā tika iekḷauti atbilstoši ehokardiogrāfiski apstiprinātam veselam aortas vārstulim. Izslēgšanas kritēriji abās grupās kontroles un AVS grupā - bija sekojoši:

- aptaukošanās; 
- saistaudu sistēmas slimības, infekcijas slimības, onkologiskas slimības;

- cukura diabēts;

- vairogdziedzera disfunkcija;

- smaga, vidēji smaga un nekontrolēta arteriāla hipertensija;

- akūts koronārais sindroms anamnēzē un manifesta koronārā sirds slimība;

- kreisā kambara sistoliska disfunkcija ar samazinātu EF zem 50\%;

- smadzeņu infarkts un tranzitora išēmiska lēkme anamnēzē;

- ehokardiogrāfiski apstiprināta kardiomiopātija;

- vizuāla AV skleroze;

- citu vārstuḷu patologijas;

- netiek lietota lipīdus zeminoša terapija.

Izslēgšanas kritērijs aortas vārstuḷa stenozes pacientu grupā bija iedzimts (piemēram, divviru aortas vārstulis) un reimatisks aortas vārstuḷa bojājums.

Visām pētījuma personām pirms iekḷaušanas pētījumā tika noteikts ABI. Iegūtie rezultāti tika vērtēti atbilstoši Amerikas Sirds asociācijas rekomendācijām (Aboyans et al., 2012): $\geq 1,4$ liecina par kalcificētu, nesaspiežamu artēriju; 1,0-1,39 - normāls ABI, ja ir mijklibošana, tad veic testu ar slodzi; ja 0,91-0,99, tad, iespējams, ka pastāv perifēro artēriju slimība; $<0,9$ - pastāv perifēro artēriju slimība; $\leq 0,5$ - smaga išēmija un $<0,4$ - kritiska išēmija.

Visiem pētījumā iekḷautajiem indivīdiem tika noteikts IMT kopējās miega artērijās; tas tika vērtēts kā normāls, ja $<0,9$ mm un nav vizualizējamas aterosklerotiskas pangas.

Visiem pētījumā iesaistītajiem indivīdiem ehokardiogrāfijas izmeklējuma laikā tika noteikta izsviedes frakcija (EF), izmantojot Simpsona metodi. Tika noteikts izsviedes tilpums (SV, no angl̦u val., stroke volume). 
Izsviedes tilpums (norma: 55-100 ml) ir asins tilpums, ko sirds kreisais kambaris izgrūž vienas saraušanās laikā. SV nosaka, no kreisā kambara beigu diastoles tilpuma (KK EDV) atņemot kreisā kambara beigu sistoles tilpumu (KK ESV), izmantojot kreisā kambara izplūdes trakta (LVOT) metodi.

\subsection{Aortas vārstuḷa stenozes diagnostika un izvērtēšana}

Visām personām pirms iekḷaušanas pētījumā tika veikta ehokardiogrāfija ar datu saglabāšanu, izmantojot ehokardiogrāfijas iekārtas: GE VIVID 7 Dimension un Philips IE 33. Katru ehokardiogrāfijas izmeklējumu izvērtēja divi ehokardiogrāfijas speciālisti. Pacienti ar aortas vārstuļa stenozi tika iedalīti trijās apakšgrupās (viegla, vidēji smaga un smaga), atkarībā no AVS smaguma pakāpes, vadoties pēc 2012. gada Eiropas Kardiologu biedrības un Eiropas Sirds un torakālo ķirurgu asociācijas darba grupas sirds vārstuḷu slimību ārstēšanas vadlīniju kritērijiem:

- $\quad$ aortas plūsmas ātrums - Vmaks. (m/s);

- vidējais spiediena gradients - PG vid. (mmHg);

- aortas vārstula atvere - AVA $\left(\mathrm{cm}^{2}\right)$;

- indeksētā aortas vārstuḷa atvere - indeksētā AVA $\left(\mathrm{cm}^{2} / \mathrm{m}^{2}\right)$.

Smaga AVS: Vmaks. $>4 \mathrm{~m} / \mathrm{s}, \mathrm{PG}>40 \mathrm{mmHg}$, AVA $<1,0 \mathrm{~cm}^{2}$, indeksētā AVA $<0,6 \mathrm{~cm}^{2} / \mathrm{m}^{2}$; vidēji smaga AVS: Vmaks. 3,0-4,0 m/s, PG 20$40 \mathrm{mmHg}$, AVA 1,0-1,5 $\mathrm{cm}^{2}$, indeksētā AVA $0,60-0,85 \mathrm{~cm}^{2} / \mathrm{m}^{2}$; viegla AVS: Vmaks. 2,5-2,9 m/s, PG $<20 \mathrm{mmHg}$, AVA $>1,5 \mathrm{~cm}^{2}$, indeksētā AVA $>0,85$ $\mathrm{cm}^{2} / \mathrm{m}^{2}$. 


\subsection{Pētījumā izmantotais materiāls}

Pētījuma analīžu veikšanai tika izmantots asins serums un plazma. Visām pētījumā iesaistītajām personām tika paņemti perifēro asinuu paraugi. Venozās asinis tika ņemtas tukšā dūšā no rīta. No asins paraugiem tika iegūta plazma un serums. Iegūto serumu un plazmu sadalīja pa koniskiem Ependorfa stobriniem (to tilpums $1,5 \mathrm{ml}$ ). Katrai pētījuma personai tika sagatavoti 7 Ependorfa stobriņi pa $200 \mu \mathrm{L}$ seruma un 5 Ependorfa stobriņi pa $200 \mu \mathrm{L}$ plazmas. Iegūtie seruma un plasmas paraugi tika uzglabāti ledusskap̄i (ar temperatūras kontroli) pie $-80{ }^{\circ} \mathrm{C}$ (Rīgas Stradiṇa universitātes Cilvēka fiziolog̣ijas un bioķīmijas katedras laboratorijāa).

\subsection{Klīniski laboratorisko rādītāju noteikšana}

Visām pētījumā iesaistītajām personām VSIA "Paula Stradiṇa klīniskā universitātes slimnīca" sertificētā laboratorijā tika noteikta asins aina (eritrocītu skaits, hemoglobīna līmenis, trombocītu skaits, leikocītu skaits, hematokrīts, eritrocītu grimšanas ātrums $(\mathrm{EGA}))$ un veiktas asins bioķīmiskās analīzes (glikoze, fibrinogēns, holesterīns ar frakcijām, C-reaktīvais proteīns), pielietojot standarta laboratoriskās noteikšanas metodes.

\section{6. Š ūnu producēto citokīnu noteikšana}

Analīzes tika noteiktas Rīgas Stradiṇa universitātes Cilvēka fiziolog̣ijas un bioķīmijas katedras laboratorijā un Rīgas Stradina universitātes Mikrobiologiijas un virusolog̣ijas institūta laboratorijā. Hemerīnu (ng/ml), FGF21 (pg/ml), MMP-1 (pg/ml), MMP-3 (ng/ml), MMP-9 (pg/ml), TIMP-1 (pg/ml), TIMP-3 (pg/ml), TGF (pg/ml) noteica pētîjuma personu asins serumā un MPO (ng/ml), TrxR1 (ng/ml) noteica asins plazmā, izmantojot enzīmu 
imūnsorbcijas testu (ELISA), bet hs-CRP (mg/l) noteica asins serumā, izmantojot Luminex xMAP tehnologiju.

MMP-1 noteikšanai asins serumā tika lietots cilvēka MMP-1 ELISA analīžu veikšanas komplekts Kat. \#EHMMP1, Pierce (Thermo Fisher Scientific), ASV; MMP-3 noteikšanais asins serumā tika pielietots cilvēka MMP-3 ELISA analīžu veikšanas komplekts Kat. \#ELH-MMP3, RayBiotech, ASV; MMP-9 noteikšanai asins serumā tika pielietots cilvēka MMP-9 ELISA analīžu veikšanas komplekts Kat. \#KHC3061, Invitrogen (Thermo Fisher Scientific), ASV; TIMP-1 noteikšanai asins serumā tika pielietots cilvēka TIMP-1 ELISA analīžu veikšanas komplekts Kat. \#ab100651, Abcam, Apvienotā Karaliste; TIMP-3 noteikšanai asins serumā tika pielietots cilvēka TIMP-3 ELISA analīžu veikšanas komplekts Kat. \#ab119608, Abcam, Apvienotā Karaliste; hemerīna noteikšanai asins serumā tika pielietots cilvēka hemerīna ELISA analǐžu veikšanas komplekts Kat. \#EZHCMRN-57 K, Merck Millipore, ASV; FGF-21 noteikšanai asins serumā tika pielietots cilvēka FGF21 ELISA analǐžu veikšanas komplekts Kat. \#EZHFGF21-19k, Merck Millipore, ASV; TrxR1 noteikšanai asins plazmā tika pielietots cilvēka tioredoksīna-1 ELISA analǐžu veikšanas komplekts prod. \#RAB1756/Lot \#0522F2032, Sigma-Aldrich, Inc., ASV; MPO noteikšanai asins plazmā tika pielietots cilvēka mieloperoksidāzes ELISA analīžu veikšanas komplekts Item. No. 501410, Cayman chemical, ASV; hs-CRP noteikšanai asins serumā tika izmantota Luminex xMAP tehnologija (Luminex TM 200; Austin, Texas, ASV) un analīžu veikšanas komplekts, Kat \# HCVD3MAG-67K, Milliplex MAP, ASV).

Rezultāti tika iegūti, izmantojot Infinite 200 PRO multimode lasītāju (Tecan grupa, Mannedorfa, Šveice) un Multiskan Ascent mikroplašu lasītāju (Thermo Labsystems, Helsinki, Somija). Procedūras tika veikta saskaņā ar ELISA komplekta ražotāja protokolu. 


\subsection{Pētījumā iegūto datu statistiskā analīze}

Visi pētījumā ietvertie grafiskie attēli, aprēķini un statistiskās analīzes tika veiktas, izmantojot IBM SPSS (Statistical Package for the Social Sciences) Statistics 23 (IBM Corp., Armonk, NY, ASV) un GraphPad Prism 7.0 software (GraphPad Software, San Diego, CA, ASV), kā arī Microsoft Excel 2013 (Microsoft, Redmond, WA, ASV) programmas.

Datu normālsadalījums tika pārbaudīts ar Brown-Forsythe un Bartlett testiem vai Kolmogorova-Smirnova vienas izlases testu. Ja datu izlases izkliede atbilda normālsadalījumam, tie tika attēloti kā vidējā vērtība (M) un standartnovirze ( \pm SD). Pretējā gadījumā dati attēloti kā mediāna un starpkvartiļu diapazons (IQR).

Normālsadalījuma datu (parametrisko datu) statistiskā analīze:

- vidējās vērtības starp divām atsevišķām grupām tika salīdzinātas, izmantojot Stjūdenta testu jeb t-testu;

- vidējās vērtības starp 3 un vairāk atsevišķām grupām tika salīdzinātas, izmantojot vienfaktora divvirzienu dispersijas analīzi (ANOVA);

Datu, kuru vērtības neatbilda normālsadalījumam (neparametriskie dati) statistiskā analīze:

- vidējās vērtības starp divām atsevišķāām grupām tika salīdzinātas, izmantojot Manna-Vitnija U-testu;

- vidējās vērtības starp 3 un vairāk atsevišķām grupām tika salīdzinātas, izmantojot Kraskela-Volesa H-testu;

Visos gadījumos kā pēcanalīze (post-hoc) tika pielietota BendžaminaKrīgera-Jekutieli (Benjamin, Krieger and Yekutieli) divpakāpju procedūra. 
Rezultātu un datu uzskatāmākai atspoguḷošanai, kas pēc sava sadalījumu vairāk atbilda logaritmiskajam datu sadalījumam, izmantoja ǵeometrisko vidējo un geometrisko standarta novirzi.

$\mathrm{P}$ vērtība mazāka par $0,05(\mathrm{p}<0,05)$ tika uzskatīta par statistiski nozīmīgu visiem pielietotajiem statistikas testiem. Kvantitatīvo mainīgo attiecību pētīšanai tika izmantota korelācijas analīzes metode. Atkarībā no datu sadalījuma un veida mēs izmantojām parametrisko Pīrsona (Pearson) vai neparametrisko Spīrmena (Spearman) korelācijas analīzi.

AV stenozes diagnostisko marķieru raksturojumam tika lietoti šādi rādītāji: ROC līkne, laukums zem ROC līknes, no tām iegūtā robežvērtība, testa jutīgums un specifiskums, pozitīvā un negatīiā prognostiskā vērtība, sasniedzot attiecīgās robežvērtības. Diagnostikas testa precizitāte tika novērtēta pēc laukuma zem ROC līknes vērtībām, atbilstoši šai klasifikācijai: 0,90-1 = lieliska; $0,80-0,90=$ laba; $0,70-0,80=$ apmierinoša; $0,60-0,70=$ slikta; un < $0,60=$ nav diagnostiskās vērtības. 


\section{REZULTĀTI}

\subsection{Pētījuma pacientu un kontroles indivīdu raksturojums}

Pētījumā iekḷauto personu pamatdati ir atspoguḷoti 2.1. tabulā. Kopumā 102 cilvēki tika iekḷauti pētījumā - 50 personas bez AVS kontroles grupā un 52 pacienti AVS grupā. AVS grupas pacienti tika sadalīti trijās AV stenozes smaguma grupās: 18 pacienti ar vieglu AVS, 19 ar vidēji smagu AVS un 15 pacienti ar smagu AVS. Koncentrēšanās uz stingriem klīniskajiem un ehokardiogrāfijas izslēgšanas kritērijiem l̦āva mums izvēlēties vispiemērotākās pētījumu grupas. Lai gan pacientu skaits apakšgrupās bija ierobežots, datu statistiskās analīzes rezultāti atklāja nozīmīgas $\mathrm{p}$ vērtības robežās no $\mathrm{p}<0,05$ līdz $\mathrm{p}<0,0001$.

Vidējais pacientu vecums visās aortas stenozes pakāpēs un kontroles grupā ir līdzīgs, un vidējais ķ̧ermeņa masas indekss (ĶMI) starp grupām neatšķiras. Triglicerīdu un zema blīvuma lipoproteīnu holesterīna (ZBL-H) vidējās vērtības statistiski starp stenozes grupām un kontroles grupu neatšķiras. Grupas ir līdzịgas attiecībā uz izsviedes frakcijas (EF) vidējām vērtībām, kas tika noteiktas pēc Simpsona metodes un izsviedes tilpuma (SV), kas tika mērīts pēc kreisā kambara izplūdes trakta metodes, kā arī saskaņā ar iekļaušanas un izslēgšanas kritērijiem. 
Kontroles grupas indivīdu un AVS grupas pacientu pamatdati

\begin{tabular}{|c|c|c|c|c|}
\hline & $\begin{array}{l}\text { Kontrole, } \\
\mathrm{n}=50\end{array}$ & $\begin{array}{c}\text { AV viegla } \\
\text { stenoze } \\
\mathrm{n}=18\end{array}$ & $\begin{array}{l}\text { AV vidēja } \\
\text { stenoze, } \\
\mathrm{n}=19\end{array}$ & $\begin{array}{c}\text { AV smaga } \\
\text { stenoze } \\
n=15\end{array}$ \\
\hline $\begin{array}{lr}\text { Dzimums, } & \text { Vīrieši } \\
(\%) & \text { Sievietes }\end{array}$ & $\begin{array}{l}11(22,0) \\
39(78,0)\end{array}$ & $\begin{array}{c}2(11,1) \\
16(88,9)\end{array}$ & $\begin{array}{c}8(42,1) \\
11(57,9)\end{array}$ & $\begin{array}{l}7(46,7) \\
8(53,3)\end{array}$ \\
\hline $\begin{array}{lr}\begin{array}{l}\text { Vecums, } \\
\text { gadi }\end{array} & M d n \\
& (I Q R) \\
\end{array}$ & $\begin{array}{c}62 \\
(57-75) \\
\end{array}$ & $\begin{array}{c}71 \\
(65-75) \\
\end{array}$ & $\begin{array}{c}74 \\
(65-79) \\
\end{array}$ & $\begin{array}{c}65 \\
(60-74) \\
\end{array}$ \\
\hline $\begin{array}{l}{ }^{\mathrm{a}} \text { ĶMI } \\
p \text { vērtība vs kontrole }\end{array}$ & $26,04(4,31)$ & $\begin{array}{c}27,39(3,10) \\
p=0,399\end{array}$ & $\begin{array}{c}25,81(4,58) \\
p=0,682\end{array}$ & $\begin{array}{c}27,40(3,18) \\
p=0,869\end{array}$ \\
\hline $\begin{array}{l}{ }^{\mathrm{b}} \mathrm{ZBL}-\mathrm{H}, \quad M( \pm S D) \\
\mathrm{mmol} / \mathrm{l} \\
\quad p \text { vertība vs kontrole }\end{array}$ & $3,28(1,18)$ & $\begin{array}{l}3,05(0,97) \\
p>0,999\end{array}$ & $\begin{array}{l}2,59(0,92) \\
p=0,057\end{array}$ & $\begin{array}{l}3,10(1,12) \\
p>0,999\end{array}$ \\
\hline $\begin{array}{l}{ }^{\mathrm{c}} \mathrm{TG}, \quad M( \pm S D) \\
\mathrm{mmol} / \mathrm{l} \\
p \text { vertība vs kontrole }\end{array}$ & $1,47(0,71)$ & $\begin{array}{l}1,64(0,84) \\
p=0,406\end{array}$ & $\begin{array}{l}1,11(0,56) \\
p=0,178\end{array}$ & $\begin{array}{l}1,27(0,57) \\
p=0,406\end{array}$ \\
\hline $\begin{array}{l}{ }^{\mathrm{d}} \mathrm{KH}, \\
\mathrm{mmol} / \mathrm{l} \\
p \text { vertība vs } \\
\end{array}$ & $5,49(1,28)$ & $\begin{array}{l}5,01(1,34) \\
p=0,056\end{array}$ & $\begin{array}{l}4,21(1,18) \\
p=0,001\end{array}$ & $\begin{array}{c}4,68(1,08) \\
p=0,016\end{array}$ \\
\hline $\begin{array}{cr}{ }^{\mathrm{e}} \mathrm{CRP}, & M d n \\
\mathrm{mg} / \mathrm{l} & (I Q R) \\
p \text { vertība vs } & \text { kontrole } \\
\end{array}$ & $\begin{array}{c}0,95 \\
(0,50-2,55)\end{array}$ & $\begin{array}{c}3,00 \\
(1,50-3,70) \\
p=0,016\end{array}$ & $\begin{array}{c}1,75 \\
(0,37-2,97) \\
p=0,37\end{array}$ & $\begin{array}{c}1,2 \\
(0,70-5,00) \\
p=0,17\end{array}$ \\
\hline $\begin{array}{rr}{ }^{\mathrm{f}} \mathrm{SV}, \mathrm{ml} & M d n \\
& (I Q R) \\
p \text { verrtība vs kontrole }\end{array}$ & $\begin{array}{c}96,5 \\
(90,0-106,3)\end{array}$ & $\begin{array}{c}100,0 \\
(90,0-110,0) \\
p=0,716\end{array}$ & $\begin{array}{c}96,0 \\
(88,0-100,0) \\
p=0,375\end{array}$ & $\begin{array}{c}90,0 \\
(88,0-95,0) \\
p=0,103\end{array}$ \\
\hline $\begin{array}{rr}{ }^{\mathrm{g}} \mathrm{EF}, \% & M d n \\
& (I Q R) \\
\text { p vērtība vs kontrole }\end{array}$ & $\begin{array}{c}63,5 \\
(57,7-68,0)\end{array}$ & $\begin{array}{c}60,0 \\
(57,5-63,5) \\
p=0,347\end{array}$ & $\begin{array}{c}61,0 \\
(58,0-66,0) \\
p=0,981\end{array}$ & $\begin{array}{c}60,0 \\
(57,0-64,0) \\
p=0,347\end{array}$ \\
\hline $\begin{array}{lr}{ }^{\mathrm{h}} \mathrm{SVI}, & M d n \\
\mathrm{ml} / \mathrm{m}^{2}, & (I Q R) \\
p \text { vērtība vs } & \text { kontrole }\end{array}$ & $\begin{array}{c}52,2 \\
(46,3-59,1)\end{array}$ & $\begin{array}{c}53,6 \\
(49,6-60,2) \\
p=0,767\end{array}$ & $\begin{array}{c}49,4 \\
(47,4-52,1) \\
p=0,288\end{array}$ & $\begin{array}{c}49,7 \\
(42,9-52,7) \\
p=0,157\end{array}$ \\
\hline
\end{tabular}

${ }^{a} \mathrm{~K} M I$ - (ķ̣ermeņa masas indekss), rādītājs, ko izsaka kā svara un kvadrātā kāpināta auguma garuma attiecību $\left(\mathrm{kg} / \mathrm{m}^{2}\right)$;

${ }^{\mathrm{b}}$ ZBL-H - zema blìvuma lipoproteīnu holesterīns;

${ }^{c} \mathrm{TG}$ - triglicerīdi;

${ }^{\mathrm{d}} \mathrm{KH}$ - kopējais holesterīns;

${ }^{\mathrm{e}} \mathrm{CRP}$ - C-reaktīvais proteins;

${ }^{\mathrm{f}} \mathrm{SV}$ - izsviedes tilpums, aprēķināts pēc kreisā kambara izplūdes trakta metodes;

${ }^{\mathrm{g}} \mathrm{EF}$ - izsviedes frakcija, aprēḳināta pēc Simsona metodes;

${ }^{\mathrm{h}} \mathrm{SVI}$ - (izsviedes tilpuma indekss), rādītājs, ko izsaka kā SV un ķermeņa virsmas laukuma attiecību $\left(\mathrm{ml} / \mathrm{m}^{2}\right)$. 


\section{2. Šūnu producēto citokīnu analīžu rezultāti}

\subsubsection{Hemerīns}

Cirkulējošos biomarķierus plaši izmanto, lai noteiktu daudzu slimību, tai skaitā kardiovaskulāro, risku. N̦emot vērā, ka hemerīns var ietekmēt iekaisuma un kalcifikācijas procesus, mēs pētījām tā nozīmi un potenciālo diagnostisko vērtību, salīdzinot kontroles grupas cilvēkus ar AVS dažādas smaguma pakāpes pacientiem. Salīdzinot kontroles grupas cilvēkus ar visiem AVS pacientiem, konstatē būtiski ( $\mathrm{p}<0,0001)$ augstāku hemerīna līmeni AVS pacientu grupā; skatīt 2.1. attēlu.

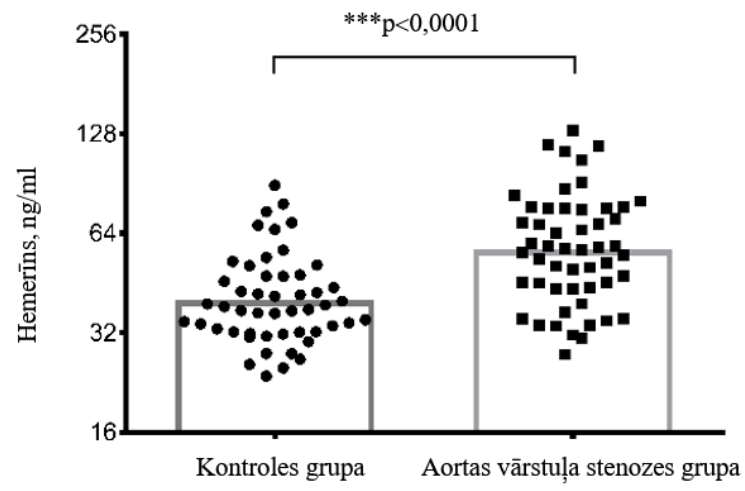

\section{1. att. Hemerīna līmenis serumā kontroles un AVS grupā}

Analizējot hemerīna līmeni pacientiem visās trijās AVS smaguma pakāpēs, iegūst statistiski nozīmīgas atšķirības salīdzinot ar kontroles grupu; skatīt 2.2. attēlu. Vieglai stenozei ir visaugstākais hemerīna līmeni $(p=0,0001)$, bet smagai stenozei - viszemākais hemerīna līmenis $(\mathrm{p}=0,042)$, salīdzinot ar kontroles grupas indivīdiem. Hemerīna līmenis samazinās, pieaugot stenozes smaguma pakāpei un smagas stenozes pacientiem novēro zemāko hemerīna 
līmeni asins serumā. Novēro būtisku atšķirīibu $(\mathrm{p}<0,05)$ starp hemerīna līmeni vieglas un smagas AV stenozes pacientiem.

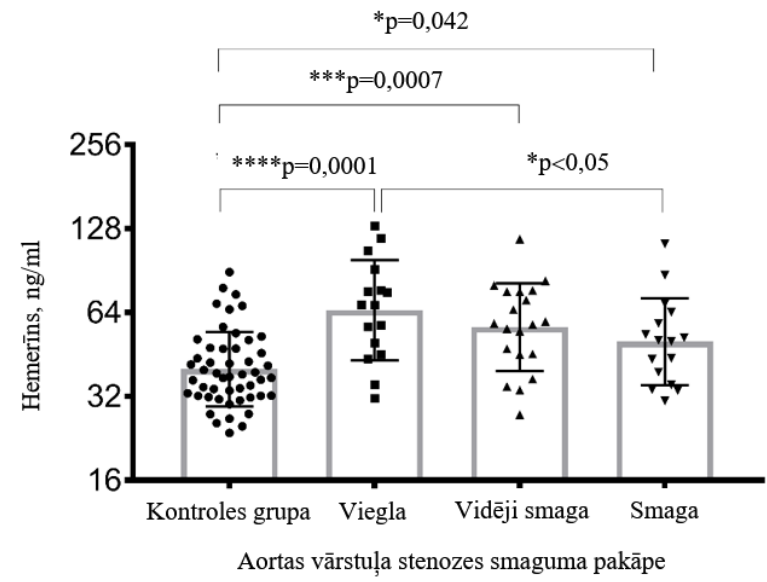

2.2. att. Hemerīna seruma līmenis kontroles grupā un pacientiem visās AVS smaguma pakāpēs

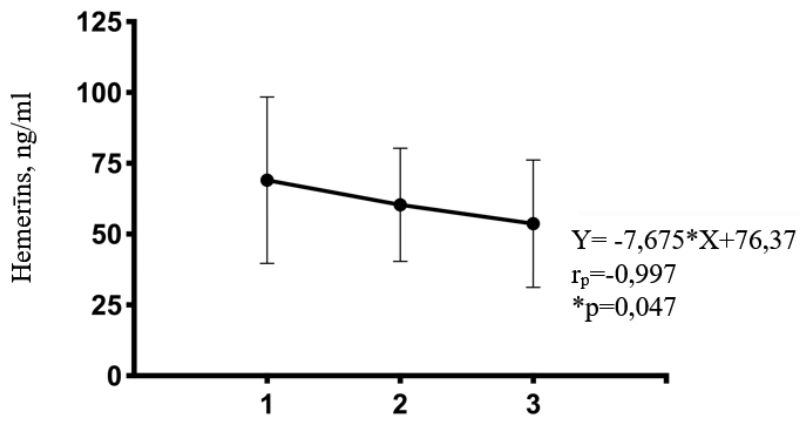

Aortas vārstuḷa stenozes smaguma pakāpe

2.3. att. Hemerīna seruma līmeṇa regresijas līkne, saistība ar AVS smaguma pakāpēm 
Veicot lineārās regresijas analīzi, vēro būtisku hemerīna līmeṇa samazināšanos, pieaugot AVS smaguma pakāpei $(p=0,047)$; skatīit 2.3. attēlu. Izvērtējot hemerīna kā biomarķiera potenciālo nozīmi, tika veikta ROC līkṇu (Receiver-Operating Characteristic Curves) analīze. No sākuma tika vērtēta seruma hemerīna diagnostiskā precizitāte visu smaguma pakāpju aortas stenozes pacientu grupā pret kontroles grupas indivīdiem; skatît 2.2. tabulu un 2.4. attēlu.

2.2. tabula

Hemerīna (ng/ml) jutīgums un specifiskums visu smaguma pakāpju (vieglas, vidējas, smagas) aortas vārstuḷa stenozes pacientiem

\begin{tabular}{|c|c|c|c|c|c|c|c|}
\hline $\begin{array}{c}{ }^{\mathrm{a}} \mathrm{AUC} \\
(95 \% \mathrm{CI})\end{array}$ & $\begin{array}{c}\mathrm{p} \\
\text { vērtība }\end{array}$ & $\begin{array}{c}\text { Robež } \\
\text { vērtība }\end{array}$ & $\begin{array}{c}{ }^{\mathrm{b}} \mathrm{Sp} \\
\%\end{array}$ & $\begin{array}{c}{ }^{\mathrm{c}} \mathrm{Se} \\
\%\end{array}$ & $\begin{array}{c}{ }^{\mathrm{d}} \mathrm{NPV} \\
\%\end{array}$ & $\begin{array}{c}{ }^{\mathrm{e}} \mathrm{PPV} \\
\%\end{array}$ & $\begin{array}{c}\text { Precizitāte } \\
\%\end{array}$ \\
\hline $\begin{array}{c}0,76 \\
(0,67-0,85)\end{array}$ & $<0,001$ & 38,60 & 55 & 80 & 72,2 & 63,6 & 67,5 \\
\hline
\end{tabular}

${ }^{a}$ AUC, laukums zem ROC līknes; ${ }^{\text {b }} \mathrm{Sp}$, specifiskums; ${ }^{\mathrm{c}}$ Se, jutīgums; ${ }^{\mathrm{d}} \mathrm{NPV}$, negatīvā prognostiskā vērtība; ${ }^{\mathrm{e}} \mathrm{PPV}$, pozitīvā prognostiskā vērtība.

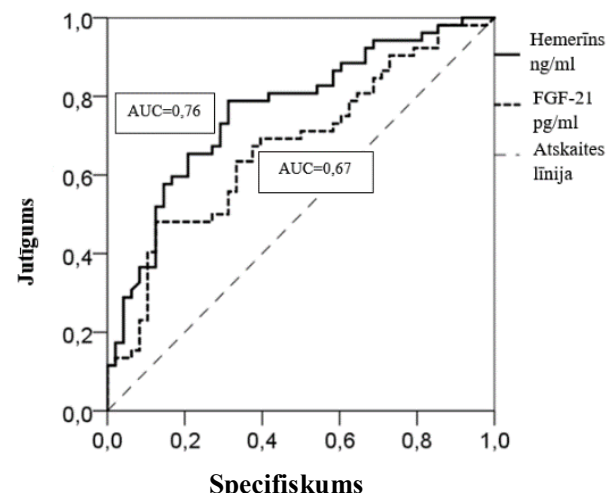

2.4. att. Hemerīna un FGF-21 kā diagnostisko marķieru ROC analīze AVS diagnostikā (iekḷauti visu smaguma pakāpju pacienti) pret kontroles grupu 
Tika izvērtēta seruma hemerīna kā iespējamā biomarķiera prognostiskā vērtība vieglas pakāpes AVS pacientiem pret kontroles grupas indivīdiem; skatìt 2.3. tabulu un 2.5. attēlu.

2.3. tabula

Hemerīna (ng/ml) jutīgums un specifiskums vieglas pakāpes aortas vārstuḷa stenozes pacientiem

\begin{tabular}{|c|c|c|c|c|c|c|c|}
\hline $\begin{array}{c}{ }^{\mathrm{a}} \mathrm{AUC} \\
(95 \% \mathrm{CI})\end{array}$ & $\begin{array}{c}\mathrm{p} \\
\text { vērtība }\end{array}$ & $\begin{array}{c}\text { Robež } \\
\text { vērtība }\end{array}$ & $\begin{array}{c}{ }^{\mathrm{b}} \mathrm{Sp} \\
\%\end{array}$ & $\begin{array}{c}{ }^{\mathrm{c}} \mathrm{Se} \\
\%\end{array}$ & $\begin{array}{c}{ }^{\mathrm{d}} \mathrm{NPV} \\
\%\end{array}$ & $\begin{array}{c}\mathrm{e} \\
\mathrm{ePV} \\
\%\end{array}$ & $\begin{array}{c}\text { Precizitāte } \\
\%\end{array}$ \\
\hline $\begin{array}{c}0,82 \\
(0,70-0,95)\end{array}$ & $<0,001$ & 43,12 & 69 & 87 & 75,5 & 71,9 & 78 \\
\hline
\end{tabular}

a AUC, laukums zem ROC līknes; ${ }^{\mathrm{b}} \mathrm{Sp}$, specifiskums; ${ }^{\mathrm{c}} \mathrm{Se}$, jutīgums; ${ }^{\mathrm{d}} \mathrm{NPV}$, negatīvā prognostiskā vērtība; ${ }^{\mathrm{e}} \mathrm{PPV}$, pozitīvā prognostiskā vērtība.

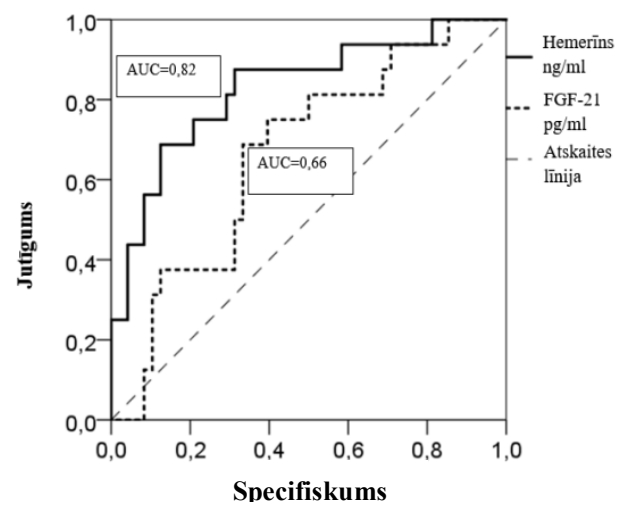

\section{5. att. Hemerīna un FGF-21 kā diagnostisko marḳieru ROC analīze vieglas AVS diagnostikā pret kontroles grupu}

Izvērtējot hemerīna kā biomarķiera potenciālo nozīmi visai AVS pacientu grupai kopā (iekḷaujot visas smaguma pakāpes) ieguvām rezultātus, ka hemerīns ir vidējs diagnostiskais marķieris: $\mathrm{AUC}=0,76 ; 0,70-0,80=$ vidējs; $\mathrm{p}<0,001 ; \mathrm{Sp}-55 \%$ un Se $-80 \%$. Tajā pašā laikā ROC analīze parādīja, ka 
seruma hemerīns ir pietiekami specifisks un jutīgs biomarķieris vieglas aortas stenozes diagnostikai: AUC $=0,82 ; 0,80-0,90=$ labs; $\mathrm{p}<0,001$; jut̄̄gums ir $87 \%$ un specifiskums ir $69 \%$.

\subsubsection{Fibroblastu augšanas faktors-21}

Visām pētījumā iesaistītajām personām tika noteikts FGF-21 asins serumā. Tika pētīta tā nozīme un potenciālā diagnostiskā vērtība, salīdzinot kontroles grupas cilvēkus ar AVS dažādas smaguma pakāpes pacientiem.

Pacientiem ar aortas vārstuḷa stenozi ir augstāks FGF-21 līmenis nekā kontroles grupas cilvēkiem ( $\mathrm{p}=0,011)$; skatīt 2.6. attēlu.

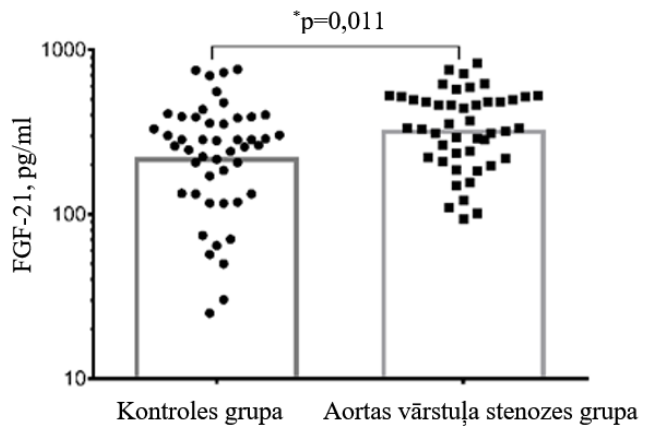

\section{6. att. FGF-21 līmenis serumā kontroles un AVS grupā}

Salīdzinot FGF-21 seruma līmeni pacientiem katrā smaguma pakāpē ar kontroles grupas indivīdiem, vēro būtisku FGF-21 pieaugumu, progresējot aortas vārstuḷa stenozei: vieglas pakāpes AVS $(p=0,013)$, vidēji smagas pakāpes AVS $(p=0,015)$ un smagas pakāpes AVS $(p=0,003)$; skatīt 2.7 . attēlu. 


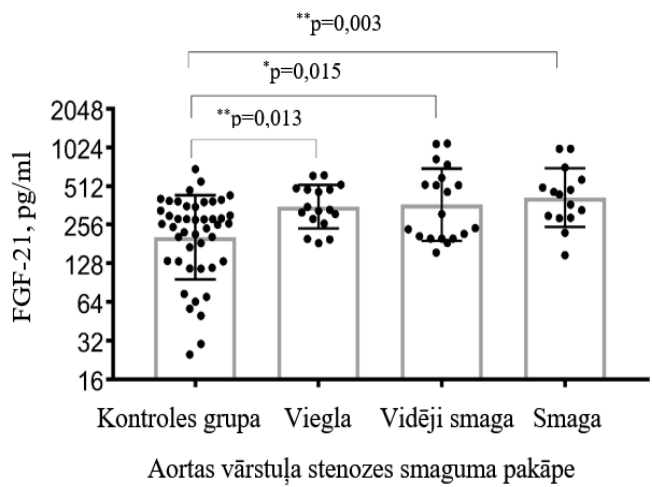

\section{7. att. FGF-21 seruma līmenis kontroles grupā un pacientiem visās AVS smaguma pakāpēs}

Veicot lineārās regresijas analīzi, novēro būtisku FGF-21 seruma līmeņa pieaugumu no vieglas līdz smagai AVS pakāpei ( $\mathrm{p}=0,0103)$. FGF-21 pieaugums visās AVS pakāpēs apliecina, ka FGF-21 atspoguḷo oksidatīvo stresu, audu bojājumu. Smagā AVS pakāpē, kad ir visizteiktākās vārstula audu pārmaiņas, atrod arī augstāko FGF-21 līmeni; skatìt 2.8. attēlu.

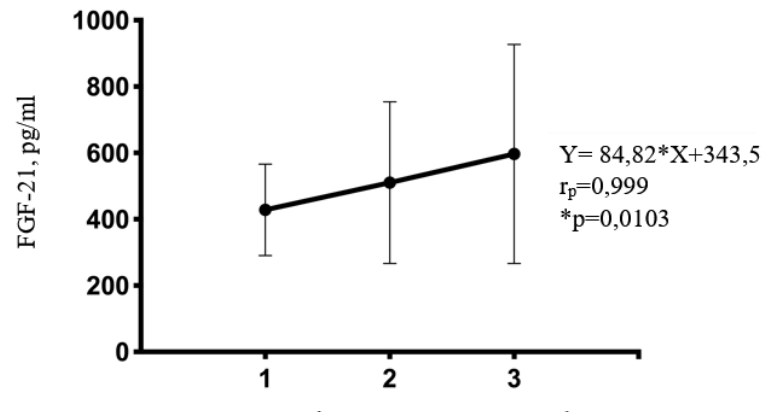

Aortas vārstuḷa stenozes smaguma pakāpe

2.8. att. FGF-21 seruma līmeṇa regresijas līkne, saistība ar AVS smaguma pakāpēm 
Izvērtējot FGF-21 kā biomarķiera patenciālo nozīmi, tika veikta ROC līkņu (Receiver-Operating Characteristic Curves) analīze. No sākuma tika vērtēta seruma FGF-21 diagnostiskā precizitāte visu smaguma pakāpju aortas stenozes pacientu grupā pret kontroles grupas indivīdiem; skatît 2.4. tabulu un 2.4. attēlu.

2.4. tabula

FGF-21 (pg/ml) jutīgums un specifiskums visu smaguma pakāpju (vieglas, vidējas, smagas) AVS pacientiem

\begin{tabular}{|c|c|c|c|c|c|c|c|}
\hline $\begin{array}{c}\mathrm{AUC}^{\mathrm{a}} \\
(95 \% \mathrm{CI})\end{array}$ & $\begin{array}{c}\mathrm{p} \\
\text { vērtība }\end{array}$ & $\begin{array}{c}\text { Robež } \\
\text { vērtība }\end{array}$ & $\begin{array}{c}\mathrm{Sp}^{\mathrm{b}} \\
\%\end{array}$ & $\begin{array}{c}\mathrm{Se}^{\mathrm{c}} \\
\%\end{array}$ & $\begin{array}{c}\mathrm{NPV}^{\mathrm{d}} \\
\%\end{array}$ & $\begin{array}{c}\mathrm{PPV}^{\mathrm{e}} \\
\%\end{array}$ & $\begin{array}{c}\text { Precizitāte } \\
\%\end{array}$ \\
\hline $\begin{array}{c}0,67 \\
(0,56-0,77)\end{array}$ & 0,003 & 309,83 & 67 & 61,5 & 61,5 & 66,6 & 64,2 \\
\hline
\end{tabular}

${ }^{a}$ AUC, laukums zem ROC līknes; ${ }^{b}$ Sp, specifiskums; ${ }^{c}$ Se, jutīgums; ${ }^{d}$ NPV, negatīvā prognostiskā vērtība; ${ }^{e} \mathrm{PPV}$, pozitīvā prognostiskā vērtība.

Tika izvērtēta seruma FGF-21 kā iespējamā biomarḳiera prognostiskā vērtība vieglas pakāpes AVS pacientiem pret kontroles grupas indivīdiem; skatìt tabulu 2.5. un 2.5. attēlu.

2.5. tabula

\section{FGF-21 (pg/ml) jutīgums un specifiskums vieglas pakāpes AVS pacientiem}

\begin{tabular}{|c|c|c|c|c|c|c|c|}
\hline $\begin{array}{c}\text { AUC }^{\mathrm{a}} \\
(95 \% \mathrm{CI})\end{array}$ & $\begin{array}{c}\mathrm{p} \\
\text { vērtība }\end{array}$ & $\begin{array}{c}\text { Robež } \\
\text { vērtība }\end{array}$ & $\begin{array}{c}\mathrm{Sp}^{\mathrm{b}} \\
\%\end{array}$ & $\begin{array}{c}\mathrm{Se}^{\mathrm{c}} \\
\%\end{array}$ & $\begin{array}{c}\mathrm{NPV}^{\mathrm{d}} \\
\%\end{array}$ & $\begin{array}{c}\mathrm{PPV}^{\mathrm{e}} \\
\%\end{array}$ & $\begin{array}{c}\text { Precizitāte } \\
\%\end{array}$ \\
\hline $\begin{array}{c}0,66 \\
(0,51-0,81)\end{array}$ & 0,04 & 283,78 & 61 & 75 & 64,4 & 65,4 & 68 \\
\hline
\end{tabular}

${ }^{\mathrm{a}}$ AUC, laukums zem ROC līknes; ${ }^{\mathrm{b}} \mathrm{Sp}$, specifiskums; ${ }^{\mathrm{c}}$ Se, jutīgums; ${ }^{\mathrm{d}} \mathrm{NPV}$, negatīvā prognostiskā vērtîba; ${ }^{\mathrm{e}} \mathrm{PPV}$, pozitīvā prognostiskā vērtība. 
Izvērtējot FGF-21 kā biomarķiera potenciālo nozīmi visai AVS pacientu grupai kopā (iekḷaujot visas smaguma pakāpes) ieguvām rezultātus, ka FGF-21 ir slikts diagnostiskais markikieris: $\mathrm{AUC}=0,67(0,56-0,77) ; \mathrm{p}=0,003 ; \mathrm{Sp}-67 \%$ un Se - 61,5\%. ROC analīze arī parādīja, ka seruma FGF-21 ir slikts diagnostiskais marķieris vieglas aortas stenozes noteikšanai: AUC $=0,66$ $(0,51-0,81) ; \mathrm{p}=0.04$; jutīgums ir $61 \%$, un specifiskums ir $75 \%$. Kopumā FGF-21 ir vērtējams kā vājš AVS biomarḳieris.

A
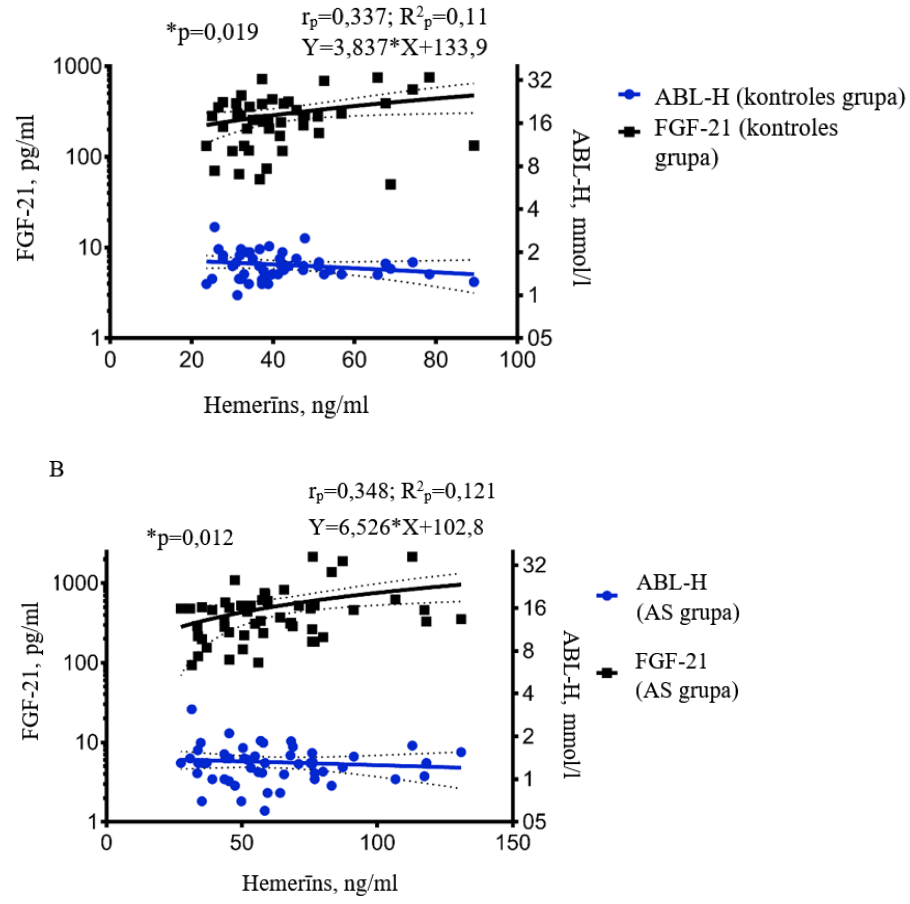

2.9. att. Korelatīvā sakarība starp seruma FGF-21 un hemerīna, hemerīna un ABL-H koncentrācijām kontroles grupai (A) un AVS grupai (B) 
Analizējot saistības starp hemerīnu, FGF-21 un ABL-H:

- Kontroles grupā atrod, ka augstāks FGF-21 līmenis ir saistîts ar augstāku hemerīna līmeni $\left(\mathrm{p}=0,019 ; \mathrm{r}_{\mathrm{p}}=0,337\right)$; nav saistības starp hemerīnu un ABL-H; skatīt 2.9.A attēlu.

- Aortas vārstuḷa stenozes pacientu grupā arī atrod līdzīgu saistību, ka augstāks FGF-21 līmenis ir saistīts ar augstāku hemerīna līmeni $\left(\mathrm{p}=0,012 ; \mathrm{r}_{\mathrm{p}}=0,348\right)$, nav saistības starp hemerīnu un ABL-H; skatīt 2.9.B attēlu.

\subsubsection{C-reaktīvais proteīns}

Mūsu pētījumā, analizējot CRP vērtības starp kontroles grupu un AVS grupas visām trim smaguma pakāpēm, tika iegūta statistiski nozīmīga atšķirīiba starp kontroles grupu un vieglas AVS grupu $(\mathrm{p}=0,016)$; skatìt 2.10. attēlu.

Vieglas AVS grupā CRP seruma līmenis ir paaugstināts, salīdzinot ar kontroles grupu, kā arī vidēju un smagu AVS grupu. Kaut arī mūsu pētījumā, cik vien varējām, izslēdzām visus iespējamos cēloņus, kas var izraisīt paaugstinātu CRP līmeni, mēs nenovērojām CRP pieaugumu, progresējot AVS pakāpei.

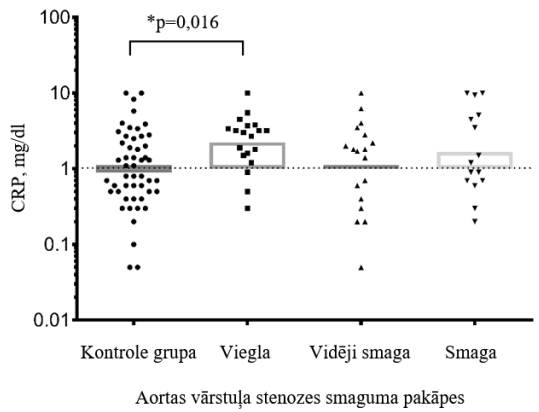

2.10. att. CRP seruma līmenis kontroles grupā un pacientiem visās AVS smaguma pakāpēs 


\subsubsection{Matrices metaloproteināzes un to audu inhibitori}

Līdz šim AVS pacientiem MMP un TIMP ir pētīts audu histologiskajos materiālos pēc veiktas aortas vārstuḷa protezēšanas operācijas.

Mēs noteicām MMP-1, MMP-3, MMP-9 un atbilstoši TIMP-1 un TIMP-3 asins serumā. Mēs varam novērtēt ne tikai kontroles grupu pret smagu AVS, bet analizēt arī MMP un TIMP līmeni visās aortas vārstuḷa stenozes pakāpēs.

Salīdzinot MMP-1 līmeni kontroles grupā un AVS grupā, konstatē būtiski augstāku ( $\mathrm{p}=0,0043)$ MMP-1 līmeni aortas vārstuḷa stenozes pacientu grupā, bet vēro multimodālu iegūto rezultātu sadalījumu; skatīt 2.11. un 2.12. attēlu.

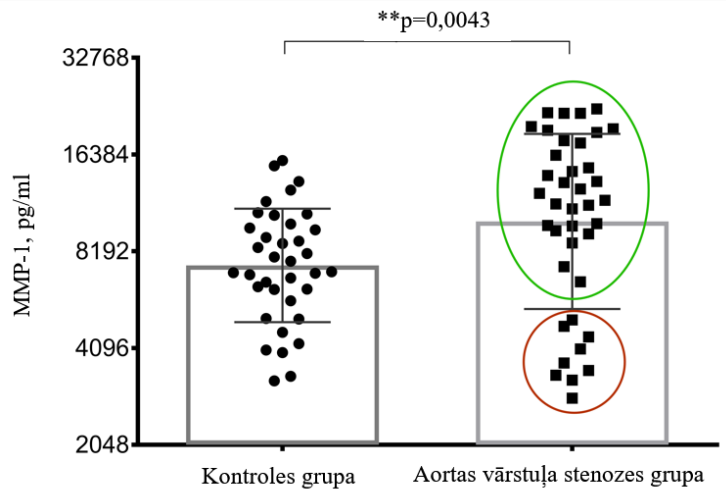

2.11. att. Seruma MMP-1 līmenis kontroles un AVS pacientu grupā, ar elipsēm iezīmēti iespējamie klasteri 


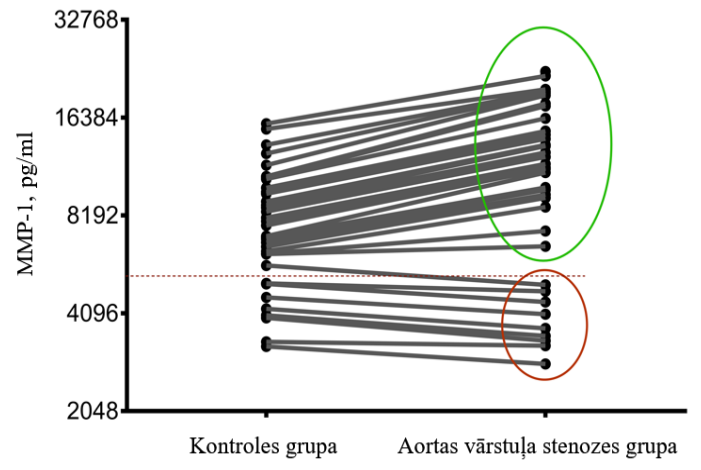

2.12. att. Seruma MMP-1 līmenis kontroles grupā un AVS pacientu grupā, ar elipsēm iezīmēti iespējamie klasteri

Lai precīzāk noteiktu, kā atšķiras AVS un kontroles grupas rezultāti, tos analizēja, izmantojot datu sadalījuma histogrammas; skatīt 2.13. un 2.14. attēlu.

MMP-1 datu sadalijuma histogramma

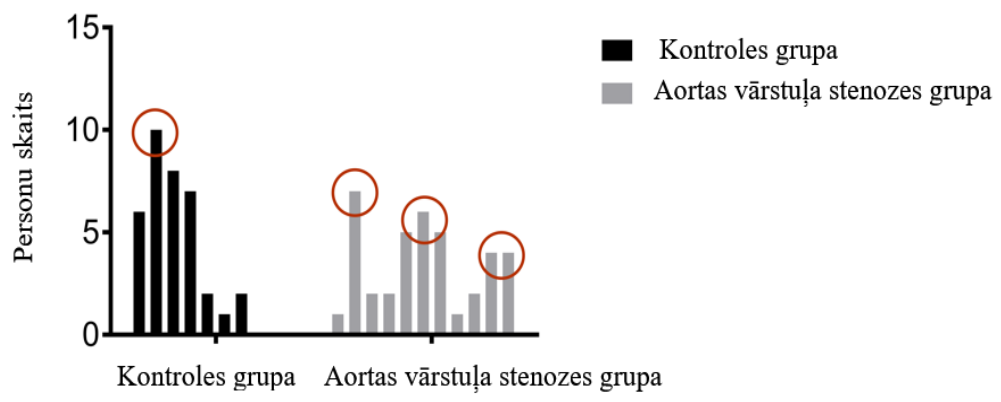

2.13. attēls. MMP-1 datu sadalījuma histogramma, ar riṇksa līnijām apvilktas modas 
MMP-1 datu sadalījuma histogramma

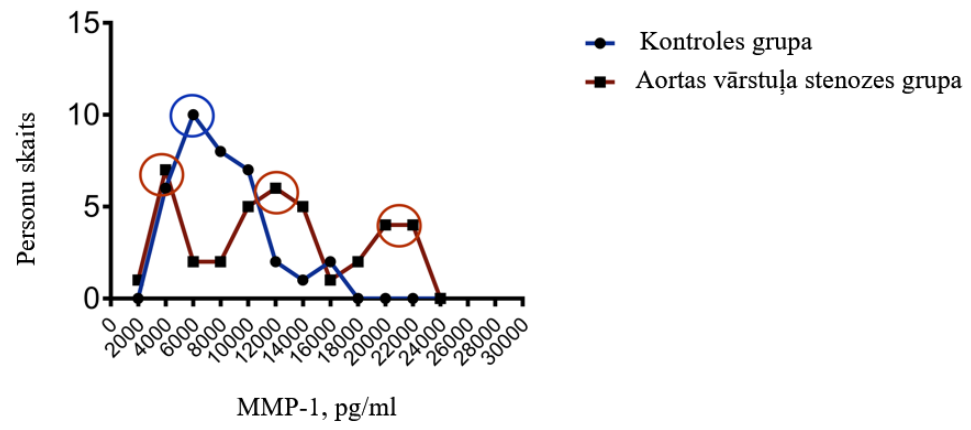

\subsection{4. att. Salīdzinošais MMP-1 datu sadalījums starp} kontroles indivīdu un AVS pacientu grupām

Ar datu sadalījuma histogrammu palīdzību noteica, ka MMP-1 rezultātu sadalījums AVS pacientu grupā ir trimodāls, bet kontroles indivīdu grupā monomodāls.

80\% pacientu aortas vārstuḷa stenozes grupā ir būtiski augstāks ( $\mathrm{p}<$ 0,0001) MMP-1 līmenis nekā kontroles grupā, bet 20\% pacientu ar aortas vārstuḷa stenozi MMP-1 līmenis ir kontroles grupas līmenī; skatīt 2.15. attēlu.

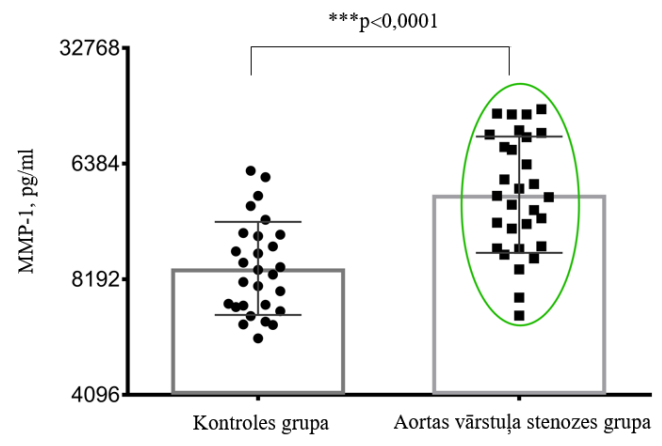

2.15. att. Seruma MMP-1 (augšejais klasters, kas atbilst $80 \%$ pacientu, skatīt 2.11. attēlu) līmenis kontroles un AVS pacientu grupā 
Analizējot MMP-1 līmeņa atšķirības starp kontroles grupu un trīs aortas vārstuḷa stenozes smaguma pakāpēm, visaugstākais MMP-1 līmenis ir vidējas AVS pakāpē $(p<0,0001)$, zemāks MMP-1 seruma līmenis ir smagas AVS pakāpē $(\mathrm{p}=0,012)$ un vēl zemāks līmenis ir vieglas aortas vārstuļa stenozes pakāpē $(p=0,031)$; skatīt 2.16. attēlu.

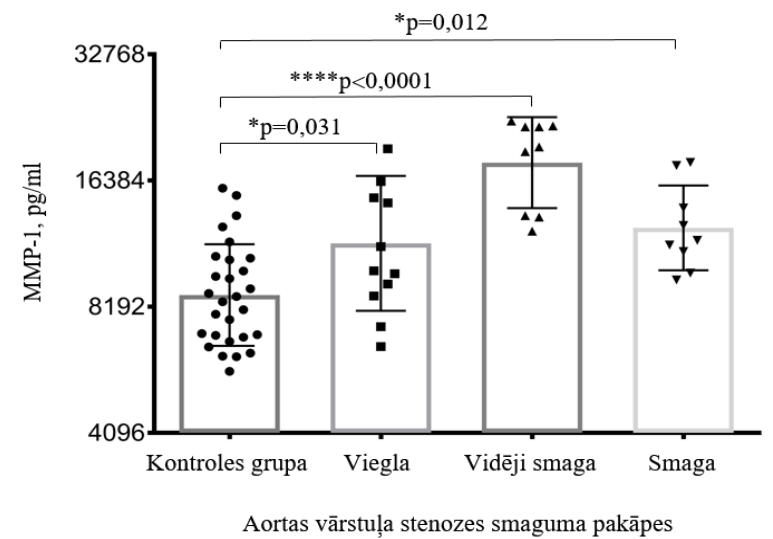

\subsection{6. att. MMP-1 seruma līmenis kontroles grupā un pacientiem visās AVS smaguma pakāpēs}

Pētījuma gaitā kontroles grupai un AVS grupas pacientiem asins serumā tika noteiktas un analizētas tādas matrices metaloproteināzes kā MMP-3 un MMP-9. Kā arī tika analizētas šīm matrices metaloproteināzēm atbilstošie audu inhibitori - attiecīgie TIMP-1 un TIMP-3. Analizējot MMP-3 seruma līmeni kontroles grupā un aortas vārstuḷa stenozes grupā, netika atrastas būtiskas atšķirības; skatīt 2.17. attēlu. 


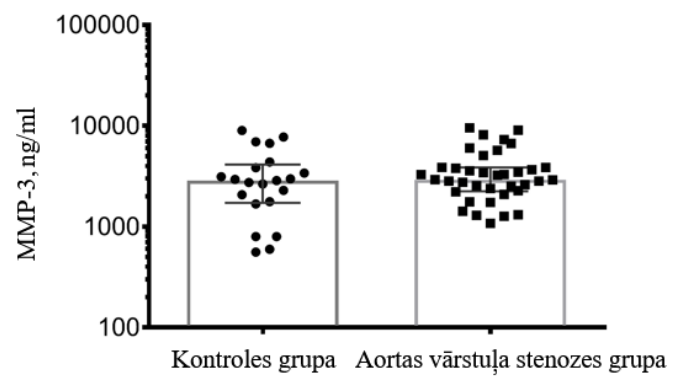

\subsection{7. att. MMP-3 seruma līmenis kontroles un AVS pacientu grupā}

Tāpat netika atrastas statistiski nozīmīgas atšķirības starp kontroles grupas indivīdiem un aortas vārstuļa stenozes pacientiem, pētījumā analizējot MMP-9 rezultātus; skatīt 2.18. attēlu.

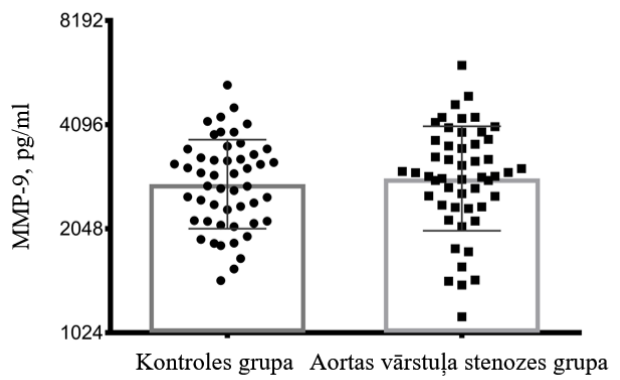

2.18. att. MMP-9 seruma līmenis kontroles un AVS pacientu grupā

Analizējot matrices metaloproteināzēm atbilstošo audu inhibitoru TIMP-1 un TIMP-3 seruma līmeņus kontroles grupā un aortas vārstuḷa stenozes grupā, netika iegūtas būtiskas atšķirības starp pētījuma grupām; skatît 2.19. un 2.20. attēlu. 


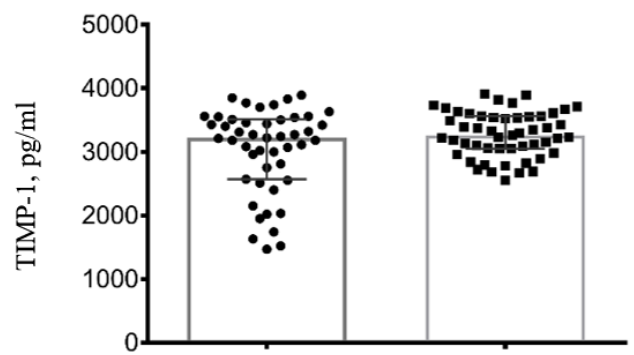

Kontroles grupa Aortas vārstuḷa stenozes grupa

2.19. att. TIMP-1 seruma līmenis kontroles un

AVS pacientu grupā

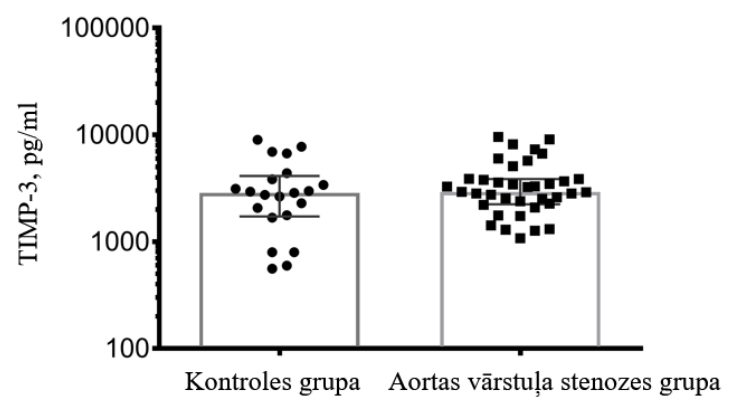

2.20. att. TIMP-3 seruma līmenis kontroles un AVS pacientu grupā

Pētījuma gaitā tika meklētas un analizētas iespējamās saistības starp MMP-1 un TIMP-1, kā arī MMP-3, MMP-9 un TIMP-3. Lai noteiktu iespējamās saistības starp matrices metaloproteināzēm, matrices metaloproteināžu audu inhibitoriem tika veiktas korelācijas analīzes; skatīt 2.21. attēlu. 


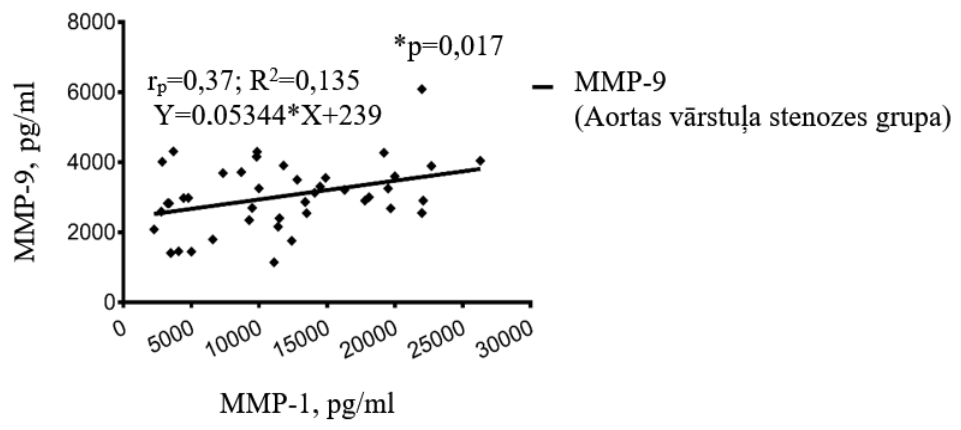

\subsection{1. att. Korelatīvā sakarība starp MMP-1 un MMP-9 koncentrāciju AVS pacientu grupā}

Veicot korelācijas analīzi starp MMP-1 un MMP-9, mēs ieguvām sakarību ( $\left.\mathrm{p}=0,017 ; \mathrm{r}_{\mathrm{p}}=0,37\right)$ : pieaugot MMP-1 līmenim aortas vārstuļa stenozes pacientiem, paaugstinās arī MMP-9 seruma līmeņi.

Pētījuma gaitā tika analizēta sakarība starp MMP-1 un MMP-3, kā arī MMP-1 un TIMP-1. Neatrod sakarību starp MMP-1 un MMP-3, kā arī starp MMP-1 un TIMP-1; skatīt 2.22. un 2.23. attēlu.

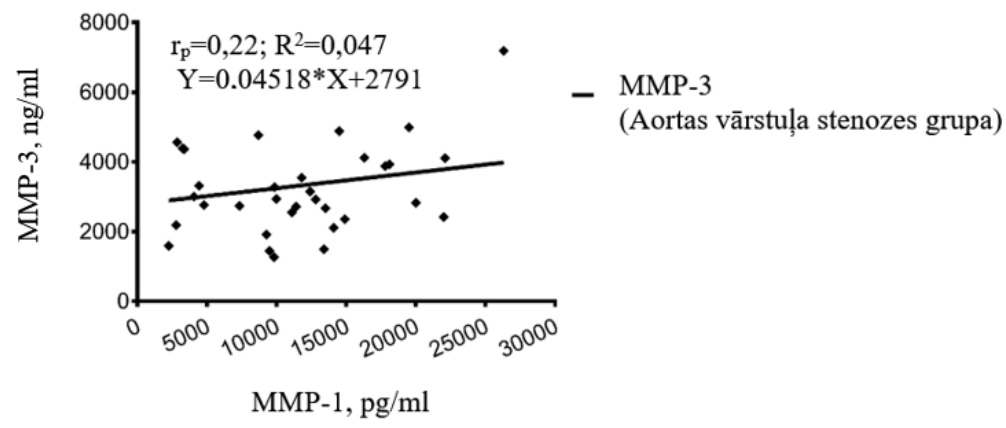

2.22. att. Korelatīvā sakarība starp MMP-1 un MMP-3 koncentrāciju AVS pacientu grupā 


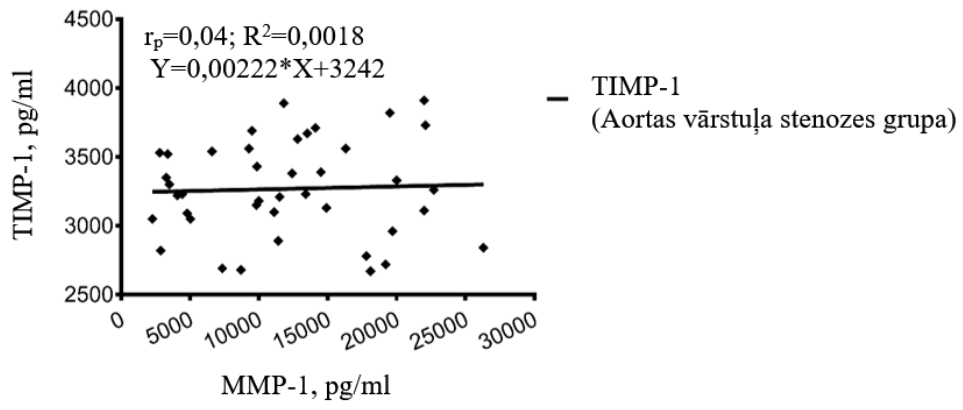

\subsection{3. att. Korelatīvā sakarība starp MMP-1 un TIMP-1 koncentrāciju AVS pacientu grupā}

Mēs savā pētījumā asins serumā starp MMP-9 un TIMP-1 neieguvām sakarību; skatīt 2.24. attēlu.

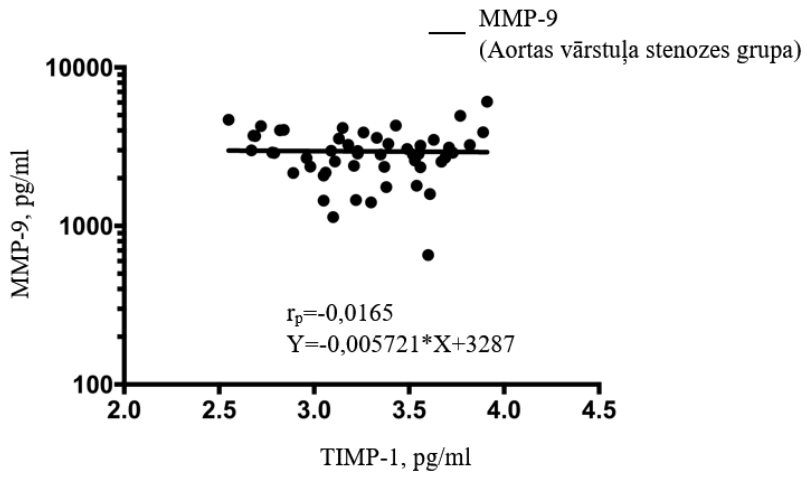

2.24. att. Korelatīvā sakarība starp TIMP-1 un MMP-9 koncentrāciju AVS pacientu grupā

Tika veikta arī korelācijas analīze starp MMP-9, MMP-3, MMP-1 un hemerīnu; skatīt 2.25., 2.26. un 2.27. attēlu. 
Ieguvām sakarību ( $\left.\mathrm{p}=0,0084 ; \mathrm{r}_{\mathrm{p}}=0,362\right)$, ka augstāks hemerīna seruma līmenis ir saistīts ar augstāku MMP-9 seruma līmeni. Tas vēl vairāk pamato MMP-9 lomu un klātbūtni aortas vārstuḷa stenozes procesā.

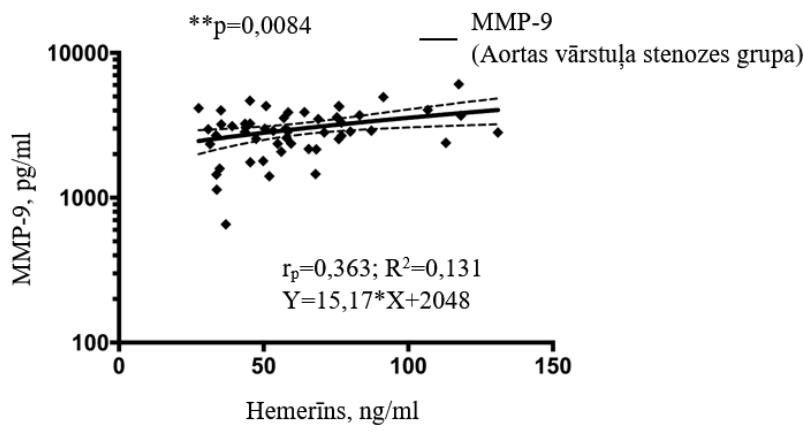

2.25. att. Korelatīvā sakarība starp hemerīna un MMP-9 koncentrāciju AVS pacientu grupā

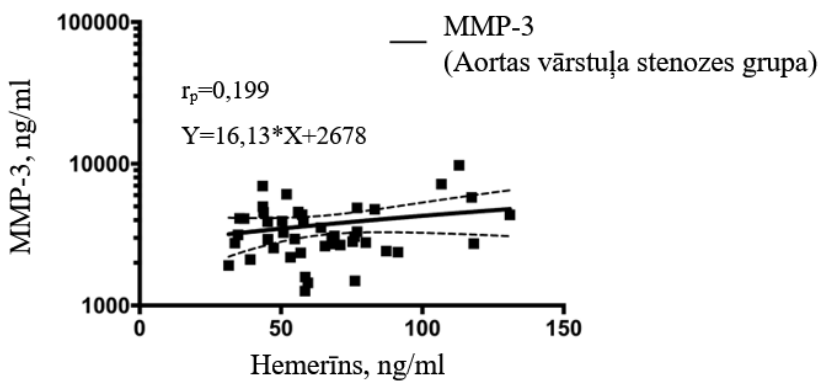

2.26. att. Korelatīvā sakarība starp hemerīna un MMP-3 koncentrāciju AVS pacientu grupā 


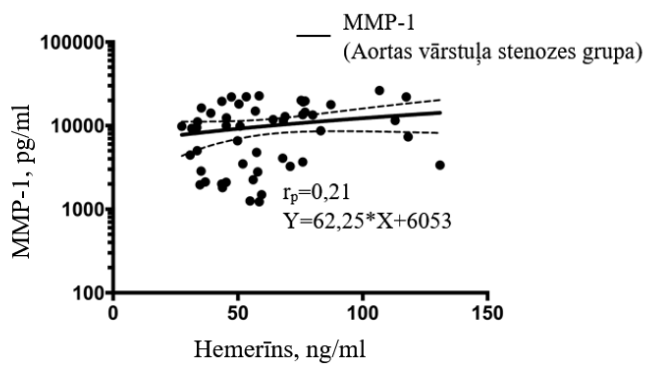

2.27. att. Korelatīvā sakarība starp hemerīna un MMP-1 koncentrāciju AVS pacientu grupā

\subsubsection{Tioredoksīna reduktāze-1}

Mēs analizējām asins plazmā antioksidantu tioredoksīna reduktāzi-1 (TrxR1). Nosakot TrxR1 līmeni plazmā kontroles grupas indivīdiem un aortas vārstuḷa stenozes pacientiem, mēs ieguvām statistiski ticami augstāku tā līmeni AVS grupā $(p=0,0016)$; skatīt 2.28. attēlu.

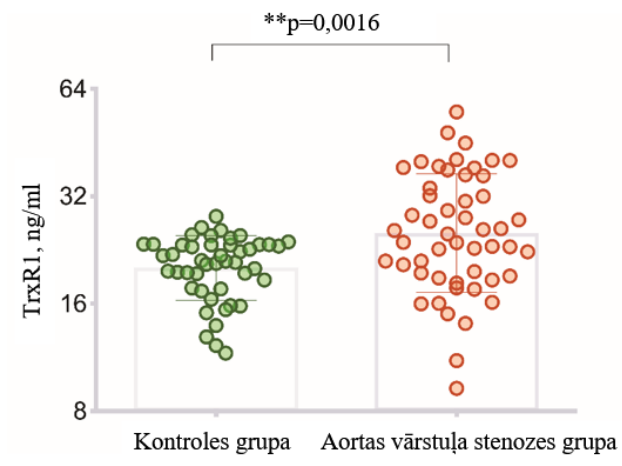

2.28. att. TrxR1 plazmas līmenis kontroles un AVS pacientu grupā 
Analizējot TrxR1 līmeņa atšķirības starp kontroles grupu un trim aortas vārstuḷa stenozes smaguma pakāpēm, iegūstam statistiski ticami $(\mathrm{p}=0,0001)$ augstāku TrxR1 līmeni vieglas aortas stenozes pakāpē un pacientiem ar smagu aortas vārstuḷa stenozi $(p=0,039)$; skatīt 2.29. attēlu.

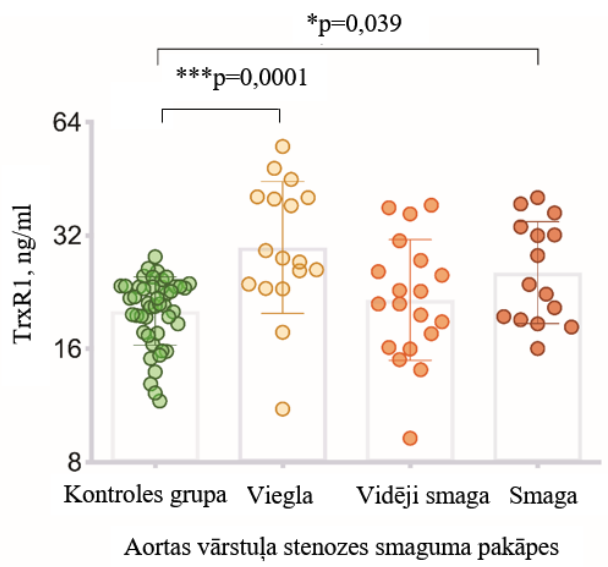

\subsection{9. att. TrxR1 plazmas līmenis kontroles grupā un pacientiem visās AVS smaguma pakāpēs}

Tika veikta korelācijas analīze ar regresijas līknes izveidi, lai analizētu un meklētu iespējamās sakarības starp TrxR1 un pārējiem biomarḳieriem.

Aortas vārstuḷa stenozes grupā ieguvām būtisku pozitīvu korelāciju starp TrxR1 un MMP-3 ( $\left.\mathrm{p}=0,013 ; \mathrm{r}_{\mathrm{p}}=0,37\right)$; skatìt 2.30. attēlu. 


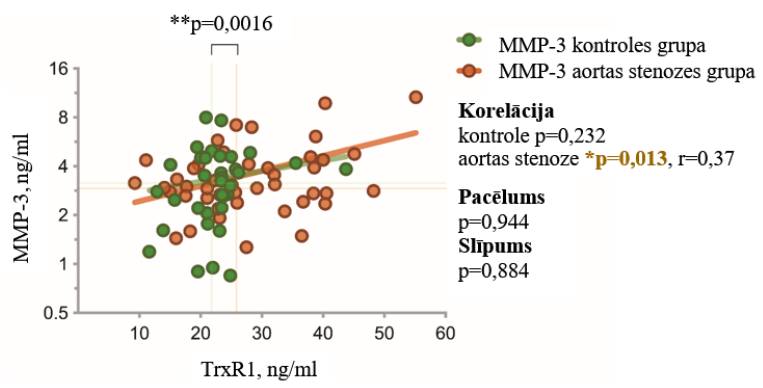

2.30. att. Korelatīvā sakarība starp TrxR1 un MMP-3

koncentrāciju kontroles grupas indivīdiem un

AVS pacientiem

Turpretī tā izpalika starp TrxR1 un MMP-9, vai bija nebūtiska starp TrxR1 un MMP-9. Tomēr TrxR1 un MMP-1 gadījumā tika konstatēta būtiska atšķirīiba starp korelāciju raksturojošo līkņu slīpumiem $(\mathrm{p}=0,0216)$, ja salīdzina kontroli ar AV stenozes grupu; turklāt pie AV stenozes korelācijai, salīdzinot ar kontroles grupu, kur novēro negatīvu virzienu $(r=-0.27)$, ir pozitīva tendence $(\mathrm{r}=0,24)$ un starpība starp abu grupu korelācijas koeficientiem, $\Delta \mathrm{r}$, sasniedz 0.51 jeb $[0.24-(-0.27)]$, t.i., paaugstinoties TrxR1 līmenim, pieaug arī MMP-1 līmenis; skatīt 3.31. attēlu.

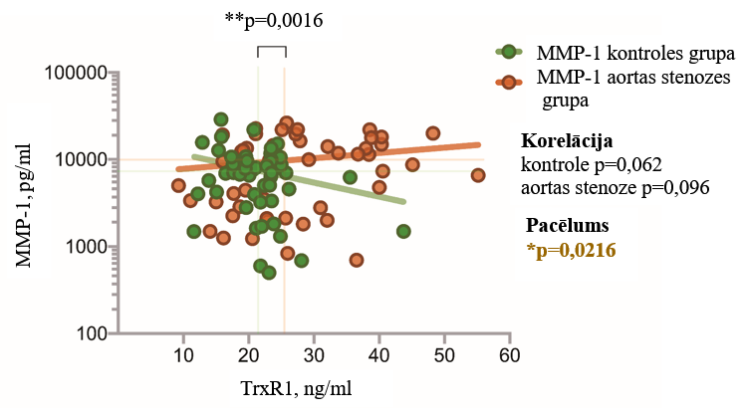

2.31. att. Korelatīivā sakarība starp TrxR1 un MMP-1 koncentrāciju kontroles grupas indivīdiem un AVS pacientiem 
Analizējot sakarību starp TrxR1 un hemerīnu (skatīt 2.32. attēlu) ar korelācijas metodes un regresijas līknes pielietošanu, tika iegūta būtiska $(\mathrm{p}=$ 0,$\left.006 ; r_{p}=0,32\right)$ pozitīva saistība starp abiem faktoriem.

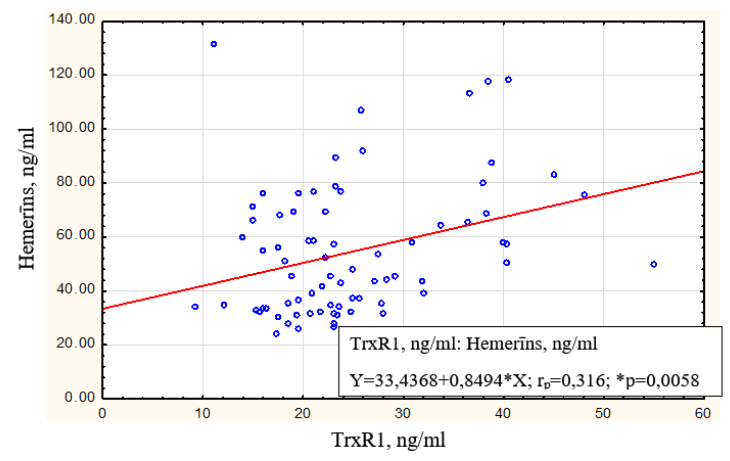

\subsection{2. att. Korelatīiā sakarība starp TrxR1 un hemerīna koncentrāciju kontroles grupas indivīdiem un AVS pacientiem}

Tāpat analizējām sakarību starp TrxR1 un FGF-21 un arī ieguvām būtisku ( $\left.\mathrm{p}=0,031 ; \mathrm{r}_{\mathrm{p}}=0,25\right)$ pozitīivu saistību; skatīt 2.33. attēlu.

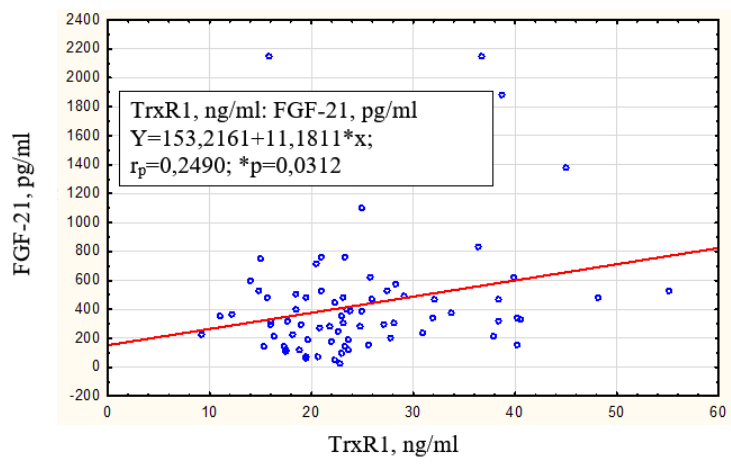

2.33. att. Korelatīvā sakarība starp TrxR1 un FGF-21 koncentrāciju kontroles grupas indivīdiem un AVS pacientiem 


\subsubsection{Mieloperoksidāze}

Tika noteikts MPO līmenis kontroles grupā un aortas vārstuļa stenozes pacientiem visās trīs aortas vārstuḷa stenozes smaguma pakāpēs. Mēs ieguvām būtisku rezultātu, ka aortas vārstuḷa stenozes pacientiem plazmas mieloperoksidāzes līmenis ir augstāks, salīdzinot ar kontroles grupu ( $\mathrm{p}<$ 0,00003). Veicot izvērstu analīzi un salīdzinot mielopertoksidāzes plazmas līmeņus starp aortas vārstuḷa stenozes smaguma pakāpēm, mēs ieguvām statistiski ticamas atšķirības visās smaguma pakāpēs no kontroles grupas ( $\mathrm{p}<0,02$ viegla stenoze; $\mathrm{p}<0,001$ vidēji smaga stenoze; $\mathrm{p}<0,0007$ smaga stenoze; skat. 2.34. attēlu). Rezultāti liecina, ka mieloperoksidāzes līmenis palielinās līdz ar aortas vārstuḷa stenozes smaguma pieaugumu un visaugstākais ir smagas stenozes pacientu grupā.

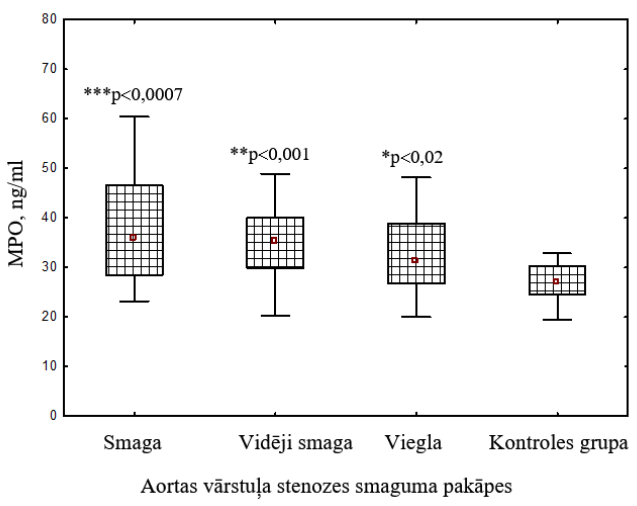

\subsection{4. att. MPO plazmas līmenis kontroles grupai un} AVS pacientiem

Ar korelācijas analīzes un regresijas līknes palīdzību mēs izskatījām sakarību starp mieloperoksidāzi (MPO) un tioredoksīna reduktāzi-1 (TrxR1); skatīt 2.35. attēlu. 


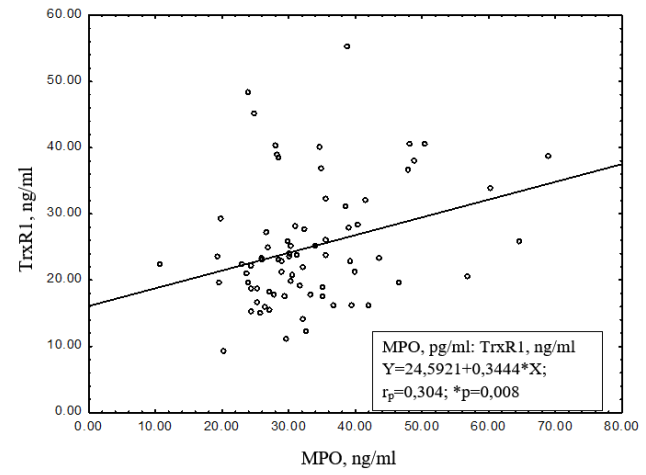

\subsection{5. att. Korelatīvā sakarība starp MPO un TrxR1} koncentrācijām kontroles grupas indivīdiem un AVS pacientiem

Ieguvām būtisku pozitīvu saistību $\left(\mathrm{p}=0,008 ; \mathrm{r}_{\mathrm{p}}=0,304\right)$. Pieaugot mieloperoksidāzes līmenim plazmā, palielinās tioredoksīna reduktāzes-1 līmenis.

Tāpat mēs izskatîjām sakarību starp MPO un hemerīnu un ieguvām būtisku pozitīvu ( $\left.\mathrm{p}=0,0057 ; \mathrm{r}_{\mathrm{p}}=0,316\right)$ saistību. Pieaugot hemerīna līmenim serumā, palielinās mieloperoksidāzes līmenis; skatīit 2.36. attēlu.

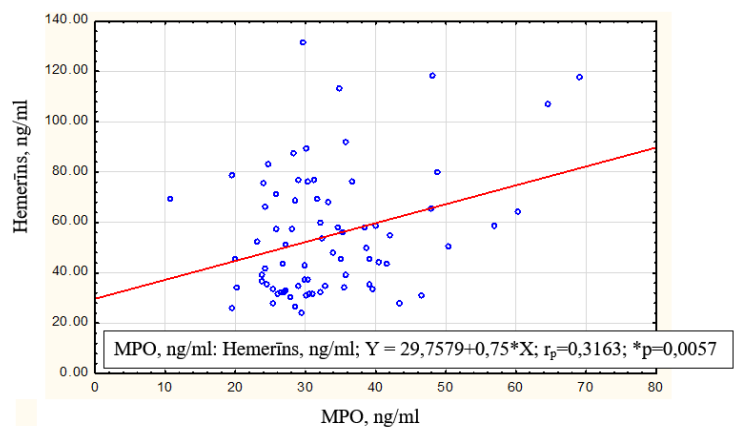

2.36. att. Korelatīvā sakarība starp MPO un hemerīna koncentrācijām kontroles grupas indivīdiem un AVS pacientiem 
Analizējot iespējamo saistību starp MPO un FGF-21, mēs neieguvām statistiski ticamas sakarības $(\mathrm{p}<0,05)$ starp šiem biomarķieriem ne kontroles grupas indivīdiem, ne aortas vārstuḷa stenozes pacientiem; skatīt 2.37. attēlu.

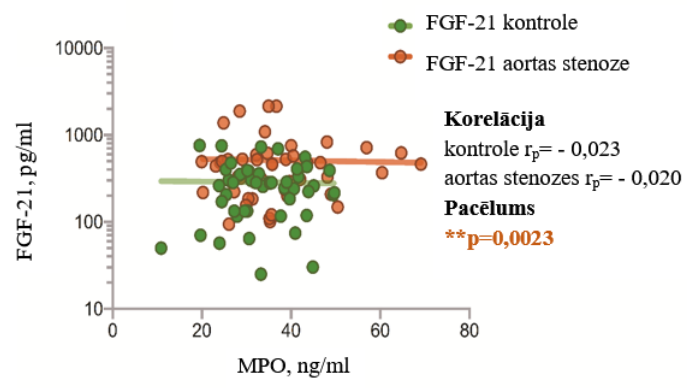

\subsection{7. att. Korelatīvā sakarība starp MPO un FGF-21 koncentrāciju kontroles grupas indivīdiem un AVS pacientiem}

Vērtējot sakarības starp mieloperoksidāzi un matrices metaloproteināzēm, mēs ieguvām būtisku, pozitīvu $\left(p=0,007 ; r_{p}=0,37\right)$ sakarību starp MPO un MMP-9; palielinoties mieloperoksidāzes plazmas līmenim aortas vārstuḷa stenozes pacientiem, pieaug arī MMP-9 līmenis; skatīt 2.38. attēlu.

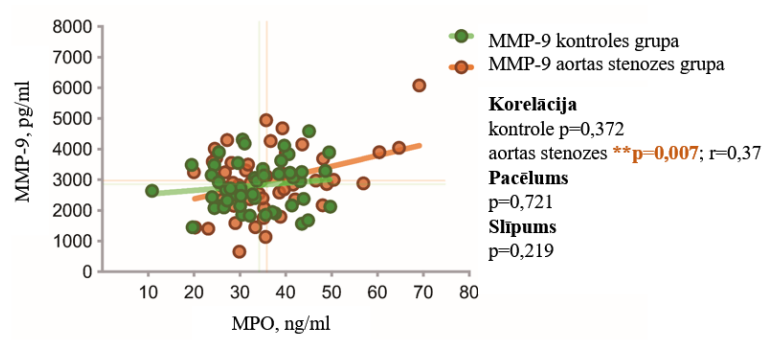

2.38. att. Korelatīvā sakarība starp MPO un MMP-9 koncentrāciju kontroles grupas indivīdiem un AVS pacientiem 
Ar korelācijas analīzes un regresijas līknes palīdzību tika iegūta statistiski ticama, negatīva $\left(\mathrm{p}=0,0474 ; \mathrm{r}_{\mathrm{p}}=-0,2791\right)$ korelācija starp MPO un ABL-H: jo augstāks ir MPO līmenis, jo zemāks ir ABL-H līmenis; skatīt 2.39. attēlu.

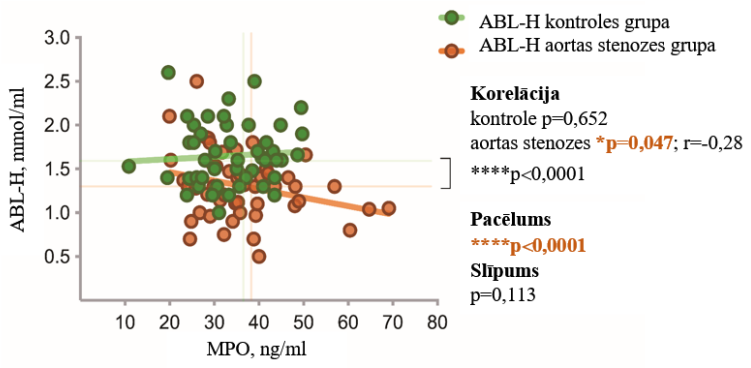

2.39. att. Korelatīvā sakarība starp MPO un ABL-H koncentrāciju kontroles grupas indivīdiem un AVS pacientiem 


\section{DISKUSIJA}

Pētījuma izstrādes laikā tika pieņemtas 2017. gada Eiropas Kardiologu biedrības un Eiropas Sirds un torakālo ķirurgu asociācijas darba grupas sirds vārstulu slimību ārstēšanas vadlīnijas (Baumgartner et al., 2017). Salīdzinot ar iepriekšêjām 2012. gada vadlīnijām, Ehokg joprojām ir galvenā diagnostikas metode, kas apstiprina AVS esamību, novērtē AV kalcifikācijas pakāpi, kreisā kambara funkciju un sieniņu biezumu, atklāj citu vārstuḷu iespējamu pavadošu patologiju un aortas patolog̣iju. Mūsu pētījumā iekļauti smagas pakāpes AVS pacienti bija ar augsta gradienta AVS, jo izslēgšanas kritēriji bija izmainīta kreisā kambara funkcija (gan AVS, gan kontroles grupā iekḷauti indivīdi ar $\mathrm{EF}>50 \%$ un SVI $>35 \mathrm{ml} / \mathrm{m}^{2}$ ). Pēc 2017. gada augstākminētajām vadlīnijām, izgulsnētā kalcija daudzuma (calcium score) noteikšana ar daudzslāņu DT palīdzību ir pirmās rindas papildizmeklējums pacientiem ar PG vid. $<40$ $\mathrm{mm} / \mathrm{Hg}, \mathrm{AVA} \leq 1,0 \mathrm{~cm}^{2}$ un $\mathrm{SVI} \leq 35 \mathrm{ml} / \mathrm{m}^{2}$. Mūsu pētījumā tādu pacientu nebija, tādēḷ arī calcium score noteikšana nebija indicēta, jo jau sākotnēji tika iekḷauti pacienti ar normālu kreisā kambara funkciju, lai izvairītos no izmeklējuma, kura pieejamība ir ierobežota un pacientu grupu veidošanas laikā vēl nepietiekami attīstīta precīzai izgulsnētā kalcija daudzuma noteikšanai. Kalcificējošas AVS etiopatoǵenēze, salīdzinot vadlīnijas un analizējot jaunāko zinātnisko rakstu atklājumus, vēl aizvien ir līdz galam neizzināta un neatklāta.

Tas, ka seruma hemerīna līmenis, pieaugot AVS smaguma pakāpei, samazinās un ir visaugstākais vieglas AVS pacientiem, liek domāt, ka darb̄̄ba vairāk notiek, hemerīnam saistoties ar Chem23 receptoru. Ja hemerīns saistītos ar GPR-1, tad tā līmenim būtu jāpieaug līdz ar AVS smaguma pakāpi un tad hemerīna līmenis serumā varētu liecināt par kalcifikācijas pakāpi; jo smagāka AVS, jo izteiktāka kalcifikācija. 
Nosakot MMP-9 seruma limmeni, netika noteiktas statistiski ticamas atšķirības starp kontroles grupu un AVS grupu, bet tika konstatēta saistība starp hemerīnu un MMP-9: augstāks MMP-9 līmenis ir saistīts ar augstāku hemerīna līmeni. Ir zināms, ka hemerīns veicina MMP-2,9,7 izdali. Veiktajos eksperimentos iegūtie rezultāti vēl vairāk pamato saistību ar iekaisuma procesu AVS pacientiem un norāda uz ekstracelulārās telpas remodelāciju jau vieglā aortas vārstuḷa stenozes pakāpē, kad ir visaugstākais hemerīna līmenis. Vēl šī saistība varētu norādīt, ka hemerīns darbojas kā iekaisuma veicinātājs.

Tika noteikta arī pozitīva saistība starp hemerīnu un antioksidantu tioredoksīna reduktāzi-1 (TrxR1): jo augstāks hemerīna līmenis, jo augstāks TrxR1 līmenis. TrxR1 galvenā loma ir aizsargāt no oksidatīvā stresa, tioredoksīns (Trx) tieši inhibē apoptozi veicinošās kināzes. Mūsu iegūtā saistība starp hemerīnu un TrxR1 norāda, ka jau no sākuma AVS attīstībā ir gan oksidatīvais stress, gan iekaisums.

Analizējot prooksidanta fermentu mieloperoksidāzi (MPO), tika iegūta pozitīvu korelatīva sakarība starp hemerīnu un MPO: pieaugot hemerīna līmenim, pieaug MPO līmenis. Hemerīnam un MPO ir zināma kopīga īpašība ietekmēt NO: hemerīns samazina NO izdali; MPO samazina NO biopieejamību un, piesaistot NO, veido ROS. Gan hemerīns, gan MPO veicina MMP izdali un ekstracelulārās telpas remodelāciju. Tas varētu norādīt, ka hemerīns aortas vārstuḷa stenozes pacientiem ir iekaisumu veicinošs.

Hemerīns var tikt izmantots par vieglas AVS labu diagnostisko marķieri. Turpmāk varētu veidot pacientu grupu ar AV sklerozi bez stenozes, lai noteiktu, vai hemerīns var prognozēt AVS attīsību.

Pēc seruma FGF-21 izmaiņām nevar viennozīmīgi spriest par šì biomarķiera lomu AVS attīstībā. FGF-21 rezultāti ḷauj pieņemt, ka FGF-21 var būt sargājoša loma AVS patoǵenēzē. Tas pamato oksidatīvā stresa klātbūtni visa AVS attīstības procesā. Fakti par FGF-21 lomu saistaudu veidošanās 
procesā (Schumacher et al., 2016) un mūsu pētījumā iegūtie dati par visaugstāko FGF-21 līmeni pacientiem ar smagu AVS var arī norādīt uz progresējošu kalcifikāciju. FGF-21 ir arī atgriezenisks efekts uz miokarda hipertrofiju, kas ir bieži sastopama AVS pacientiem. Arī šis var būt viens no izskaidrojumiem, kāpēc FGF-21 pieaug līdz ar AVS smagumu. Jāmeklē citi oksidatīvā stresa biomarķieri un jāsalīdzina rezultāti, lai precīzāk izteiktos par FGF-21 nozīmi AVS attīstībā.

FGF-21 un TrxR1 ir saistīti ar oksidatīvo stresu: uzlabo oksidatīvo kapacitāti, samazina ROS iedarb̄̄bu, samazina šūnu apoptozi, piedalās audu atjaunošanā. Starp abiem faktoriem atrod pozitīvu korelatīvu saistību: jo augstāks FGF-21 līmenis, jo augstāks TrxR1 līmenis. Tas parāda abu šo faktoru mijiedarbību un oksidatīvā stresa un iekaisuma saistību. Tika atrasta arī pozitīva saistība starp FGF-21 un hemerīnu. N̦emot vērā to, ka visaugstākais FGF-21 līmenis ir smagā aortas vārstuļa stenozes pakāpē un tam ir korelatīvs ciešums gan ar TrxR1, gan ar hemerīnu, varētu pieņemt, ka hemerīns darbojas kā iekaisuma faktors, bet FGF-21 aortas vārstuḷa stenozes attīstības sākumā ir saistīts ar pretiekaisuma darbību. Visaugstākais FGF-21 līmenis smagā AVS pakāpē var būt saistīts gan ar progresējošu kalcifikāciju, gan darbību, kas vērsta pret miokarda hipertrofiju.

Par FGF-21 vairāk varētu uzzināt, nosakot IL-6 un TNF- $\alpha$ līmeni asins serumā, jo šie biomarķieri atbild par iekaisuma procesu un ir atkarīgi no FGF-21.

C-reaktīvā proteīna statistisko datu rezultāts l̦auj teikt, ka augsts CRP līmenis var liecināt par sākotnēju kalcificējošu AVS. Pēc mūsu pētījuma datiem CRP nevar izmantot, lai paredzētu AVS progresēšanas ātrumu. Mūsu dati ir līdzīgi datiem no pētījuma, kur vērtēja hs-CRP saistību ar AVS (Cho et al., 2016). 
Darbā analizētie MMP (MMP-3, MMP-9) un TIMP (TIMP-1, TIMP-3) līmeņi asins serumā neuzrādīja statistiski būtiskas atšķirīibas starp kontroles grupas indivīdiem un AVS pacientiem.

Analizējot MMP-1, tika noteikts būtiski augstāks tā līmenis AVS grupā, turklāt ar trimodālu rezultātu sadalījumu. $80 \%$ iegūto vērtību AVS grupā ir būtiski augstākas nekā kontroles grupā. Visaugstākais MMP-1 līmenis ir vidējā AVS pakāpē. Iegūtie dati par visaugstāko MMP-1 līmeni vidējā aortas vārstuḷa stenozes pakāpē var norādīt uz to, ka šajā aortas vārstuḷa stenozes pakāpē ir visizteiktākā ekstracelulārās telpas remodelācija ar kolagēna šksiedru degradāciju un osteoblastu diferenciāciju un kalcifikāciju.

Mūsu pētījumā 20\% aortas vārstuḷa stenozes pacientiem MMP-1 līmenis nepieauga un palika kontroles grupas līmen̄i. Analizējot šos pacientus, izrādījās, ka visiem šiem pacientiem ir viegla aortas vārstuḷa stenoze. Mēs domājam, ka to var izskaidrot ar aprakstīto MMP-1 polimorfismu. 1G alēlei ir aizsargājoša darbība pret kalcija nogulsnēšanos, bet $2 \mathrm{G}$ alēles nesējiem (gan homozigotiem, gan heterozigotiem) ir izteiktāka aortas vārstuḷa kalcinoze (neatkarīgi no vecuma, dzimuma un nieru funkcijas) (Solache-Berrocal et al., 2016). Būtu izzinoši turpmāk apsekot un regulāri novērot šos $20 \%$ vieglas pakāpes aortas stenozes pacientus, kam nebija paaugstināts MMP-1 līmenis, jo teorētiski šiem pacientiem varētu prognozēt lēnu aortas vārstuḷa stenozes progresēšanu.

Mūsu pētījumā iegūtie dati par MMP-1 līmeņa izmaiņām dažādās aortas vārstuḷa stenozes pakāpēs (zemākais MMP-1 līmenis smagas aortas vārstuļa stenozes pacientiem; skatīt 2.16. attēlu), atbilst citu pētījumu rezultātiem no operāciju laikā iegūtā histoloǵiskā materiāla. Zemāks MMP-1 līmenis smagas AVS pacientiem var liecināt, ka šajā slimības pakāpē iekaisuma process ir neaktīvs vai zemas aktivitātes, un ir izveidojusies kalcinoze. 
Mēs neatradām sakarību starp MMP-1 un TIMP-1 seruma līmeņiem. Tas liek domāt, ka aortas vārstuḷa stenozes ekstracelulārās telpas remodelācijā iesaistītās MMP-1 līmenis un darbība netiek regulēta ar TIMP-1 palīdzību.

Mēs pētījumā neatradām statistiski ticamas atšķirīibas TIMP-1 seruma līmen̄̄ starp aortas vārstuḷa stenozes pacientiem un kontroles grupu. Arī citos pētījumos konstatēja individuāli mainīgu, tomēr nebūtisku TIMP-1 līmeni gan stenotiskajos, gan kontroles grupas vārstuḷos (Kaden et al., 2005).

Veicot korelācijas analīzi starp MMP-1 un MMP-9, mēs ieguvām sakarību, ka pieaugot MMP-1 līmenim aortas vārstuḷa stenozes pacientiem, pieaug arī MMP-9 seruma līmenis. Salīdzinot mūsu rezultātus ar citu pētnieku atklājumiem, var pieņemt, ka MMP-9 funkcionē lokāli šūnu līmenī.

Tā kā MMP-9 ir pierādīts kā nozīmīgs aterosklerozes biomarķieris, bet mūsu pētījumā tam nav būtiskas atšķirības no kontroles grupas, tas tikai atkārtoti apliecina, ka aortas vārstuļa stenoze ir atšķirīgs process no aterosklerozes.

Ir pētīta MMP un TIMP ekspresija nereimatiskas aortas vārstula stenozes gadījumā. Arī šajos histologiskajos pētījumos atrada disproporciju starp MMP-9 un TIMP-1. Tika novērota MMP-9 lokalizācija ap kalcifikācijas mezgliņiem.

Ieguvām sakarību, ka augstāks hemerīna seruma līmenis ir saistīts ar augstāku MMP-9 seruma līmeni. Tas vēl vairāk pamato MMP-9 lomu un klātbūtni aortas vārstuḷa stenozes procesā.

Tioredoksīna reduktāzes-1 analīzes rezultāti parāda, ka oksidatīvais stress ir saistīts ar kalcificējošu aortas vārstuḷa stenozi. Visaugstāks TrxR1 līmenis pacientiem ar vieglu AVS un pozitīva sakarība ar hemerīnu un FGF-21 parāda, ka TrxR1 labi atspoguḷo oksidatīvā stresa augstu izteiktību vieglā aortas stenozes pakāpē. 
Atšķirībā no FGF-21, kura līmenis pieauga līdz ar aortas vārstuḷa stenozes smagumu, TrxR1 līmenis ir mainīgs - visaugstākais vieglas aortas vārstuḷa stenozes pakāpē un zemāks smagas aortas vārstul̦a stenozes pakāpē, viszemākais vidējas stenozes pakāpē. To varētu izskaidrot ar to, ka smagā AVS pakāpē ir vērojama kreisā kambara hipertrofija, ko sastop daudziem smagas aortas vārstuḷa stenozes pacientiem. Ir pierādīts, ka miokarda hipertrofija veicina TrxR1 ekspresiju (Yamamoto et al., 2003). Otrs iemesls varētu būt sirds mazspēja, jo ir pierādīts, ka jo izteiktāka sirds mazspēja, jo augstāks tioredoksīna līmenis (Jekell et al., 2004).

Aortas vārstuḷa stenozes pacientiem atradām pozitīvu saistību starp TrxR1 un MMP-1: augstāks TrxR1 līmenis ir saistīts ar augstāku MMP-1 līmeni. Tā kā MMP-1 atrod gan ekstracelulāri, gan intracelulāri, tad jādomā, ka tas saistīts ar oksidatīvo stresu un ekstracelulārās telpas remodelāciju.

Iepriekš, pētot MMP-1, MMP-3, MMP-9, mēs neatradām korelācijas, kas pierādītu MMP-3 lomu aortas vārstuḷa stenozes procesā. Tas, ka mēs atrodam AVS pacientiem būtisku pozitīvu korelāciju starp tioredoksīna reduktāzi-1 un MMP-3, l̦auj teikt, ka arī MMP-3 ir nozīme aortas vārstuḷa stenozes procesā.

Starp TrxR1 un MMP-9 atradām nelielu saistību, un to var izskaidrot ar jau iepriekš iegūtajiem rezultātiem un citu pētnieku publicētajiem datiem, kas parāda, ka MMP-9 vairāk lokalizēta ap kalcifikācijas zonām.

Nosakot MPO līmeni, mēs to ieguvām statistiski ticami augstāku aortas vārstula stenozes pacientiem, piekam, pieaugot no vieglas līdz smagai aortas vārstuḷa stenozes pakāpei. MPO ir pozitīva saistība ar TrxR1, hemerīnu un MMP-9. MPO darbību vajadzētu izskaidrot dažādi:

- pozitīvo saistību ar TrxR1 un hemerīnu varētu izskaidrot ar endotēlija disfunkciju, ROS veidošanu un aktīvu līdzdalību iekaisuma un oksidatīvā stresa procesos; 
- pozitīvā saistība ar MMP-9, no vienas puses, pierāda MMP-9 lomu aortas vārstula stenozes procesā, bet, no otras puses, zinot, ka MMP9 pamatā atrod lokāli ap kalcifikācijas zonām, un MPO satur kalcija saistīšanās vietu, var izteikt domu, ka MPO varētu piedalīties kalcifikācijas procesā.

Tomēr to nevar viennozīmīgi apgalvot, jo MPO, iedarbojoties caur ROS un ox-ZBL, var aktivēt MMP.

Saistība starp MPO un ABL-H līmeņiem atbilst MPO nelabvēlīgajai iedarbībai, paaugstinot ox-ZBL-H līmeni, radot ABL-H disfunkciju un oxABL-H veidošanos, līdz ar to vēl vairāk mazinot ABL-H aizsardzību. Tas notiek arī MPO veidotās hipohlorskābes ietekmēe, kura oksidē apoA-1 un samazina ABL-H aizsargājošo darbību. Tā kā augstākais MPO līmenis ir smagas aortas vārstuḷa stenozes pacientiem, tad attiecīgi zemākā ABL-H aizsardzība arī ir šajā AVS pakāpē. Mums nav iespēju tieši ietekmēt MPO darbību, bet, jo augstāks būs ABL-H līmenis pacientiem, jo labāka būs ABL-H aizsargājošā loma.

Ja TrxR1 pieaugumu smagā AVS pakāpē mēs skaidrojam ar sirds mazspēju, kreisā kambara hipertrofiju, tad MPO un ABL-H saistība pamato oksidatīvo stresu smagā aortas vārstuḷa stenozes pakāpē.

MPO līmenis, tāpat kā FGF-21 līmenis, pieaug, progresējot stenozei. Tas norāda uz oksidatīvā stresa esamību aortas vārstuḷa stenozes attīstībā. Ne MPO, ne TrxR1, ne FGF-21 līmenis smagas aortas vārstuḷa stenozes pacientiem nav zemākā līmenī kā vidēji smagas stenozes pacientiem, bet ar tendenci būt augstākam, kas liecina, ka oksidatīvais stress ir visās AVS smaguma pakāpēs. Atšķirīịi no hemerīna, kas ir labs vieglas aortas vārstuḷa stenozes biomarķieris un tā līmenis samazinās, progresējot AVS, iegūtie rezultāti ar MPO un TrxR1 liek domāt, ka vidēji smagā un smagā aortas stenozes pakāpē prevalē jau minētais oksidatīvais stress un progresējoša kalcifikācija. 
Analizējot oksidatīvā stresa marķieru (MPO un TrxR1) iespējamo saistību ar pārējām šūnu producētām regulējošām molekulām (citokīniem), atrodam pozitīvu sakarību starp MPO un MMP-9, kā arī MMP-3. Tas varētu norādīt, ka gan MMP-9, gan MMP-3 ir saistīti ar aortas vārstuḷa stenozes attīstību un varbūt piedalās oksidatīvā stresa izraisītā ekstracelulārās telpas remodelācijā.

Tas, ka oksidatīvā stresa līmenis ir relatīvi lielāks smagā aortas stenozes pakāpē nekā vidējā, varētu tikt izskaidrots ar izmaiņām, kas radušās AVS progresēšanas rezultātā: sirds mazspēju, kreisā kambara hipertrofiju un zemu koronārās plūsmas rezervi. 


\section{SECINĀJUMI}

1. Aortas vārstuḷa stenozes grupas pacientu sadalījums trijās smaguma pakāpēs un izvērtējums attiecībā pret kontroles grupu liauj precīzāk un pilnvērtīgāk spriest par slimības patoǵenēzi.

2. Hemerīns ir labs diagnostisks biomarķieris vieglai aortas stenozes pakāpei.

3. Ekstracelulārās telpas remodelācija sākas vieglā aortas vārstuḷa stenozes pakāpē un visizteiktākā ir vidējā aortas stenozes smaguma pakāpē. Noteikts būtisks MMP-1 koncentrācijas pieaugums gan vieglā AVS pakāpē, gan izteiktāk vidējā AVS pakāpē. Noteikta pozitīva saistība starp MMP-1 un MMP-9, hemerīnu un MMP-9.

4. Iegūtie rezultāti pamato iekaisuma un oksidatīvā stresa klātbūtni visās trijās AVS smaguma pakāpēs. Visaktīvākais iekaisuma process ir vieglā AVS pakāpēe, kur hemerīna līmenis ir būtiski visaugstākais, bet sakarības starp biomarķieriem parāda, ka jau vieglā AVS pakāpē sākas oksidatīvais stress visbūtiskākais TrxR1 līmeņa palielinājums ir vieglā AVS pakāpē, savukārt MPO līmenis būtiski (salīdzinot ar kontroli) pieaug līdz ar AVS smagumu, sasniedzot visaugstāko līmeni smagā AVS pakāpē. Lielāku oksidatīvā stresa līmeni smagā AVS pakāpē mēs saistam ar to, ka turpinās gan oksidatīvais stress, gan to, ka lielākajai daļai smagas pakāpes AVS pacientu ir attīstījušās komplikācijas kā kreisā kambara hipertrofija, hroniska sirds mazspēja.

5. Oksidatīvais stress un iekaisums ir savstarpēji saistīti procesi, ko pamato hemerīna pozitīvā korelatīvā sakarība ar TrxR1 un MPO.

6. Pirmās hipotēzes dạ̧u par iekaisuma faktoru un citokīnu lomu AVS attīstībā pierāda: hemerīna, FGF-21, CRP, MMP-1, TrxR1, MPO statistiskās analīzes rezultāti; korelatīvās sakarības starp MMP-1 un MMP-9 un hemerīnu, 
arī starp TrxR1 un MMP-3. To, vai šie faktori un citokīni nosaka AVS prognozi, vēl nevar spriest. Tam nepieciešami ǵenētiski pētījumi.

7. Ir apstiprināta otrā hipotēze: noteikta ABL-H būtiska nozīme AVS pacientiem - konstatēta negatīva korelatīvā sakarība starp MPO un ABL-H, kur augstāks MPO līmenis ir saistīts ar zemāku ABL-H līmeni. Smagas AVS pacientiem ir augstākais MPO līmenis, ko var izskaidrot ar MPO darbību, veidojot ox-ABL-H un mazinot ABL-H aizsargājošo darbību, tādējādi, jo augstāks būs ABL-H līmenis pacientiem, jo labāka būs ABL-H aizsargājošā loma.

8. Ir noteikts, ka oksidatīvais stress ir visās AVS smaguma pakāpēs un tam ir saistība ar iekaisuma procesu, apstiprinot arī trešo hipotēzi. 


\section{PRAKTISKĀS REKOMENDĀCIJAS}

1. Hemerīns un tā noteikšana asins serumā ir labs diagnostiskais marķieris vieglas AS pacientiem. To varētu rekomendēt noteikt pacientiem, kam izklausa sirds trokšnus līdz laikam, kamēr nav veikta ehokardiogrāfija, arī pacientiem, kuriem samazinātas kreisā kambara sistoliskās funkcijas dēl diagnostikā ir grūti izšķirties starp vieglas un vidējas stenozes pakāpēm. Hemerīna noteikšanu asins serumā teorētiski varētu izmantot pacientiem ar vizuālu AV sklerozi un pacientiem ar paaugstinātu spiediena gradientu uz AV, bet bez AVA, indeksētā AVA samazinājuma dinamiskai novērošanai.

2. Būtu iespējams veidot vieglas AVS pacientu novērošanas un dinamiskas izmeklēšanas programmu, lai noteiktu AVS progresēšanas ātrumu un saistību ar MMP-1 1G alēli, kuras nesējiem teorētiski būtu jānovēro lēna slimības progresēšana. Tas varētu parādīt genētisko faktoru lomu AVS pacientiem.

3. Laboratorisko rezultātu saistība ar oksidatīvo stresu un iekaisumu un zināmais par AVS patoǵenēzi liek pievērst īpašu uzmanību vieglas AVS pacientiem, jo šajā pakāpē no patoǵenēzes viedokḷa ir iespējams novērst vai kavēt slimības progresēšanu. Varētu veikt pētījumus ar medikamentiem, kas ietekmē iekaisuma procesu. Jau iepriekš bijuši mēǵinājumi lietot citostātiskus medikamentus, bet to radītās blaknes neatsvēra klīnisko ieguvumu.

4. Lai arī lipīdiem un statīnu terapijai nav tiešas saistības ar AVS procesu, ko pamato arī mūsu veiktās analīzes, tomēr gan ox-ZBL-H, gan ABL$H$ ir saistīti ar AVS. Jācenšas maksimāli palielināt ABL-H līmeni visu AVS pakāpju pacientiem, lai saglabātu un uzlabotu ABL-H aizsargājošo lomu oksidatīvā stresa apstākḷos. Tā kā nav sevišķu iespēju tieši ietekmēt MPO darbību, jāpievērš īpaša uzmanība ABL-H līmenim pacientu asinīs - jo tas būs augstāks, jo spēcīgāka būs tā aizsargājošā loma. 


\section{LITERATŪRAS SARAKSTS}

1. Aboyans, V., Criqui, M. H., Abraham, P., Allison, M. A., Creager, M. A., Diehm, C., Fowkes, F. G., Hiatt, W. R., Jönsson, B., Lacroix, P., Marin, B., McDermott, M. M., Norgren, L., Pande, R. L., Preux, PM., Stoffers, H. E., Treat-Jacobson, D. 2012. American Heart Association Council on Peripheral Vascular Disease; Council on Epidemiology and Prevention; Council on Clinical Cardiology; Council on Cardiovascular Nursing; Council on Cardiovascular Radiology and Intervention, and Council on Cardiovascular Surgery and Anesthesia. Measurement and interpretation of the ankle-brachial index: a scientific statement from the American Heart Association. Circulation. 126 (24), 2890-909. doi: 10.1161/CIR.0b013e318276fbcb

2. Baumgartner, H., Falk,V., Bax, J.J., De Bonis, M., Hamm, C., Holm, P. J., Iung, B., Lancellotti, P., Lansac,E., Muñoz, D. R., Rosenhek, R., Sjögren, J., Mas, P. T., Vahanian, A., Walther, T., Wendler, O., Windecker, S., Zamorano, J. L. 2017. ESC Scientific Document Group, ESC/EACTS Guidelines for the management of valvular heart disease. European Heart Journal. 38(36), 2739-2791. doi: 10.1093/eurheartj/ehx391

3. Bonow, R., Greenland, P. 2015. Population-Wide Trends in Aortic Stenosis Incidence and Outcomes. Circulation. 131(11), 969-971. doi: https://doi.org/10.1161/CIRCULATIONAHA.115.014846

4. Cho, K.I., Cho, S.H., Her, A-Y., Singh, G.B., Shin, E-S. 2016. Prognostic Utility of Neutrophil-to-Lymphocyte Ratio on Adverse Clinical Outcomes in Patients with Severe Calcific Aortic Stenosis. PLoS One. 11(8):e0161530. doi: 10.1371/journal.pone.0161530. eCollection 2016

5. Chow, W. S., Xu, A., Woo, Y. C., Tso, A. W. K., Cheung, S. C. W., Fong, C. H. Y., Tse, H. F., Chau, M. T., Cheung, B. M. Y., Lam, K. S. L. 2013. Serum Fibroblast Growth Factor-21 Levels Are Associated With Carotid Atherosclerosis Independent of Established Cardiovascular Risk Factors. Arteriosclerosis, Thrombosis, and Vascular Biology. 33, 2454-2459 doi: 10.1161/ATVBAHA.113.301599

6. Eveborn G. W., Schirmer H., Heggelund G., et al. 2013. The evolving epidemiology of valvular aortic stenosis. The Tromsø study. Heart. 99 (6), 396-400. doi: 10.1136/heartjnl-2012-302265

7. Heistad, D. D., Wakisaka, Y., Miller, J., Chu, Y., Pena-Silva, R. 2009. Novel Aspects of Oxidative Stress in Cardiovascular Diseases. Circ J. 73 (2), 201-207. doi: 10.1253/circj.CJ-08-1082

8. Jekell, A., Hossain, A., Alehagen, U., Dahlström, U. and Rosén, A. 2004. Elevated circulating levels of thioredoxin and stress in chronic heart failure. European Journal of Heart Failure, 6, 883-890. doi:10.1016/j.ejheart.2004.03.003

9. Kaden, J. J., Dempfle, C. E., Grobholz, R. et al. 2005. Inflammatory regulation of extracellular matrix remodeling in calcific aortic valve stenosis. Cardiovascular Pathology. 14 (2), 80-87. doi: 10.1016/j.carpath.2005.01.002

10. Kanwar, A., Thaden, J. J., Nkomo, V. T. 2018. Management of Patients With Aortic Valve Stenosis. Mayo Clinic Proceedings. 93 (4), 488-508. doi: 10.1016/j.mayocp.2018.01.020 
11. Kleinauskienė, R., Jonkaitienè, R. 2018. Degenerative Aortic Stenosis, Dyslipidemia and Possibilities of Medical Treatment. Medicina 54(2), 24. doi: 10.3390/medicina54020024

12. Lindman, B. R., Clavel, M. A., Mathieu, P., lung, B., Lancellotti, P., Otto, C. M., Pibarot, P. 2016. Calcific aortic stenosis. Nat Rev Dis Primers. 3; 2: 16006 . doi: 10.1038/nrdp. 2016.6

13. Nagase, H., Visse, R., Murphy, G. 2006. Structure and function of matrix metalloproteinases and TIMPs. Cardiovascular Research. 69 (3), 562-573. doi: 10.1016/j.cardiores.2005.12.002

14. Oury, C., Nchimi, A., \& Lancellotti, P. 2019. Editorial: From Biology to Clinical Management: An Update on Aortic Valve Disease. Frontiers in cardiovascular medicine. 6, 4. doi:10.3389/fcvm.2019.00004

15. Pawade, T. A., Newby, D. E., Dweck, M. R. 2015. Calcification in Aortic Stenosis. The Skeleton Key. Journal of the American College of Cardiology. 66 (5), 561-577. doi: 10.1016/j.jacc.2015.05.066

16. Perrot, N., Boekholdtb, S.M., Mathieua, P., Warehamc, N.J., Khawd, K-T., Arsenault, B.J. 2018. Life's simple 7 and calcific aortic valve stenosis incidence in apparently healthy men and women et al. International Journal of Cardiology. 269, 226 - 228. doi: 10.1016/j.ijcard.2018.07.107

17. Schumacher, J. D., Guo, G. L. 2016. Regulation of Hepatic Stellate Cells and Fibrogenesis by Fibroblast Growth Factors. Biomed Res Int. 2016 (8323747). doi: $10.1155 / 2016 / 8323747$

18. Solache-Berrocal, G., Barral, A., Martín, M., Román-García, P., Llosa, J.C., NavesDíaz, M., Cannata-Andía, J.B., Rodríguez, I. 2016. The association of MMP1 $1 \mathrm{G}>2 \mathrm{G}$ polymorphism with aortic valve. Rev Osteoporos Metab Miner 8 (4), 115120. http://scielo.isciii.es/pdf/romm/v8n4/en_original2.pdf

19. Vahanian A., Alfieri O., Andreotti F., Antunes M. J., Barón-Esquivias G., Baumgartner H., Borger M. A., Carrel T.P., De Bonis M., Evangelista A., Falk V., Lung B., Lancellotti P., Pierard L., Price S., Schäfers H. J., Schuler G., Stepinska J., Swedberg K., Takkenberg J., Von Oppell U. O., Windecker S., Zamorano J. L., Zembala M. 2012. ESC Committee for Practice Guidelines (CPG); Joint Task Force on the Management of Valvular Heart Disease of the European Society of Cardiology (ESC); European Association for Cardio-Thoracic Surgery (EACTS). Eur J Cardiothorac Surg. 42 (4), S1-44. doi: 10.1093/ejcts/ezs455

20. Yamamoto, M., Yang, G., Hong, C., Liu, J., Holle, E., Yu, X., Wagner, T., Vatner, S.F., Sadoshima, J. 2003. Inhibition of endogenous thioredoxin in the heart increases oxidative stress and cardiac hypertrophy. J. Clin. Investig. 112, 1395-1406. doi: $10.1172 / \mathrm{JCI} 200317700$

21. Zeng, Q., Song, R., Fullerton, D. A., Ao, L., Zhai, Y., Li, S., Ballak, D. B., Cleveland, J. C., Reece, T. B., McKinsey, T. A., Xu, D., Dinarello, C. A., Menga, X. 2017. Interleukin-37 suppresses the osteogenic responses of human aortic valve interstitial cells in vitro and alleviates valve lesions in mice. Proc Natl Acad Sci U S A. 114 (7), 1631-1636. doi: 10.1073/pnas.1619667114 


\section{PUBLICĒTIE RAKSTI, ZIŅOJUMI PAR DARBA TĒMU}

\section{Publikācijas recenzētos medicīniskajos izdevumos}

1. Hofmanis, J., Hofmane, D., Svirskis, S., Mackevics, V., Tretjakovs, P., Lejnieks, A., Signorelli, S.S. HDL-C Role in Acquired Aortic Valve Stenosis Patients and Its Relationship with Oxidative Stress. Medicina. 2019; 55(8), 416. doi: 10.3390/medicina55080416

2. Tretjakovs, P., Hofmanis, J., Hofmane, D., Krieviņa, G., Blumfelds, L., Mackēvičs, V., Lejnieks, A., Bahs, G. 2019. Prognostic Utility Of Novel Biomarkers In Aortic Valve Stenosis. Proceedings of the Latvian Academy of Sciences, Section B: Natural, Exact, and Applied Sciences. doi: 10.2478/prolas-2019-0016

3. Lurins, J., Lurina, D., Svirskis, S., Nora- krukle, Z., Tretjakovs, P., Mackevics, V., Lejnieks, A., Rapisarda, V., Baylon, V. Impact of several proinflammatory and cell degradation factors in patients with aortic valve stenosis. Experimental And Therapeutic Medicine. 2019; 17, 2433-2442. doi: 10.3892/etm.2019.7254

4. Lurins, J., Lurina, D., Tretjakovs, P., Mackevics, V., Lejnieks, A., Rapisarda, V., Baylon, V. Increased serum chemerin level to predict early onset of aortic valve stenosis. Biomed Rep. 2018; 8 (1), 31-36. doi: 10.3892/br.2017.1010

5. Lūriņš, J., Veinberga, L., Lūriņa, D., Tretjakovs, P., Mackēvičs, V. Augsta blīvuma lipoproteīna nozīme un saistība ar iekaisuma faktoriem un iegūtu aortas vārstuḷa stenozi. RSU Zinātniskie raksti. Internā medicīna 2017, 16-26.

6. Lurins, J., Visocka, A., Mackevics, V., Tretjakovs, P. Kalcificējošas aortas vārstuḷa stenozes biomarķieru - hemerīna un FGF-21 - diagnostiskais novērtējums. $R S U$ Zinātniskie raksti. Internā medicīna 2016, 72-81.

7. Lūriņš, J., Mackēvičs, V., Tretjakovs, P., Zeidlers, I. Aortas vārstuḷa stenozes saistība ar bioķīmiskiem marķieriem. RSU Zinātniskie raksti. Internā medicīna $2014,47-56$.

\section{Mutiskie ziņojumi kongresos un konferencēs}

1. Impact of several proinflammatory and degeneration factors in aortic valve stenosis. J. Lurins, D. Lurina, P. Tretjakovs, V. Mackevics, A. Lejnieks, V. Rapisarda, V. Baylon. 22 $2^{\text {nd }}$ World Congress on Advances in Oncology and 20th International Symposium on Molecular Medicine. Athens, Greece, 2017, October 5-7

2. Plasma thioredoxin reductase and myeloperoxidase levels in acquired aortic valve stenosis patients. J. Lurins, D. Lurina, G. Krievina, V. Mackevics, P. Tretjakovs, A. Lejnieks, S. S. Signorelli. 23 ${ }^{\text {rd }}$ World Congress on Advances in Oncology and $22^{\text {nd }}$ International Symposium on Molecular Medicine. Athens, Greece, 2018, September $20-22$ 


\section{Tēzes kongresos un konferencēs}

1. Hofmanis, J., Hofmane, D., Gersone, G., Svirskis, S., Mackevics, V., Tretjakovs, P., Lejnieks, A. The role of oxidative stress in calcific aortic valve stenosis patients. Abstract. International conference knowledge for use in practice. Rīga Stradin̄š University, Riga, Latvia, 2019, April 1-3.

2. Lurins, J., Lurina, D., Krievina, D., Mackevics, V., Tretjakovs, P., Lejnieks, A., Signorelli, S. S. Plasma thioredoxin reductase and myeloperoxidase levels in acquired aortic valve stenosis patients. Abstract. $23^{\text {rd }}$ World Congress on Advances in Oncology and $22^{\text {nd }}$ International Symposium on Molecular Medicine. Athens, Greece, 2018, September 20-22

3. Lurins, J., Lurina, D., Tretjakovs, P., Mackevics, V., Lejnieks, A., Rapisarda, V., Baylon, V. Impact of several proinflammatory and degeneration factors in aortic valve stenosis. Abstract. $22^{\text {nd }}$ World Congress on Advances in Oncology and $20^{\text {th }}$ International Symposium on Molecular Medicine. Athens, Greece, 2017, October 5-7.

4. Lurins, J., Lurina, D., Tretjakovs, P., Mackevics, V. Increased serum chemerin level predicts the early onset of aortic valve stenosis. Abstract. The 40th Scientific meeting of the ELC. Tutzing, Germany, 2017, September 4-7.

5. Lurins, J., Visocka, A., Krievina, G., Mackevics, V., Tretjakovs, P. Serum chemerin and fibroblast growth factor-21 levels in acquired aortic valve stenosis patients. Abstract. The 85th EAS Congress. Prague, Czech Republic, 2017, April 23-26.

6. Lurins, J., Visocka, A., Mackevics, V., Tretjakovs, P. Aortic valve stenosis in association with inflammatory process and biochemical markers. The 84th EAS Congress. Innsbruck, Austria, 2016, May 29-June 1.

7. Lurins, J., Visocka, A., Mackevics, V., Tretjakovs, P. Bioķīmiskie marķieri iegūtas aortas vārstuḷa stenozes patoǵenēzē. RSU zinātniskās konferences tēzes. Rīga, 2016. gada 17.-18. marts. 45. lpp.

8. Lūriņš, J., Mackēvičs, V., Tretjakovs, P. Bioķīmisko parametru novērtējums pacientiem ar aortālā vārstuḷa stenozi. RSU zinātniskā konferences tēzes. Rīga, 2015. gada 26. un 27. marts. 125. lpp.

9. Lurins, J., Tretjakovs, P., Mackēvičs, V. Aortic valve stenosis relation with biochemical markers. Abstract. Atherosclerosis. 2015, 241 (Issue 1), e142. doi: 10.1016/j.atherosclerosis.2015.04.491

10. Lūriņš, J., Mackēvičs, V., Tretjakovs, P., Zeidlers, I. Iegūta aortas vārstuḷa stenoze: etiopatoǵenēzes aspekti. RSU zinātniskā konferences tēzes. Rīga, 2014. gada 10. un 11. aprīlis. 170 . lpp. 